Acta Crystallographica Section A

Foundations of

Crystallography

ISSN 0108-7673

\section{Report of the Executive Committee for 2007}

\section{Meetings}

The IUCr sponsored the following meetings held during 2007:

BCA Intensive Course in X-ray Structure Analysis, Durham, UK, 4 March - 2 April.

Latin-American Workshop on Applications of Powder Diffraction and School on Methods of Powder Diffraction, Campinas, Brazil, 1620 April.

RapiData 2007, Brookhaven, USA, 22-27 April.

6th International Conference on Inelastic X-ray Scattering (IXS 2007), Hyogo, Japan, 7-11 May.

Fifth International Conference on Solid State Crystals and Eighth Polish Conference on Crystal Growth (ICSSC-5 and PCCG-8), Zakopane, Poland, 20-24 May.

Engineering of Crystalline Materials Properties: State-of-the-Art in Modelling, Design, Applications, Erice, Italy, 7-17 June.

Crystallization: Focus on Membrane Proteins, Brookhaven, USA, 11-15 June.

School and Workshop on X-ray Micro- and Nanoprobes: Instruments, Methodologies and Applications, Erice, Italy, 11-17 June.

Gordon Research Conference on Electron Distribution and Chemical Bonding, South Hadley, USA, 1-6 July.

First School on Materials Applications of the Organic Solid State (SMAOSS) and XVIII International Conference on the Chemistry of the Organic Solid State (XVIII-ICCOSS), 1-6 and 8-13 July.

XVI International Conference on Crystal Chemistry and Diffraction Studies of Minerals and Workshop 'Minerals as Advanced Materials', Miass and Apatity, Russia, 2-6 and 8-12 July.

International School on Theoretical and Mathematical Crystallography, Havana, Cuba, 15-20 July.

ACA Annual Meeting, Salt Lake City, USA, 21-26 July.

International Conference on Neutron and X-ray Scattering, Serpong and Bandung, Indonesia, 23-31 July.

13th International Summer School on Crystal Growth, Park City, USA, 5-11 August.

VIII Latin-American Workshop on Magnetism and Magnetic Materials and Their Applications (LAW3M), Rio de Janeiro, Brazil, 12-16 August.

9th International Biology and Synchrotron Radiation Conference, Manchester, UK, 12-17 August.

ECM-24, Marrakech, Morocco, 22-27 August.

Symposium in Honour of Professor Dame Louise Johnson, FRS, DBE, Oxford, UK, 2-5 September.

Advanced Methods in X-ray Charge Density Analysis: Extracting Properties from a Multipolar Refinement, Martina Franca, Italy, 3-6 September.

Electron Microscopy and Multiscale Modelling, Moscow, Russia, 3-7 September.

Structure Elucidation by Combining Magnetic Resonance, Computation, Modelling and Diffraction (SMARTER), Aveiro, Portugal, 6-7 September.
Advances in Crystallography at High Pressure at Large-Scale Facilities, Chilton, UK, 6-9 September.

Diffraction Analysis of the Microstructure of Materials, Garmisch-

Partenkirchen, Germany, 7-9 October.

Synchrotron Radiation and Neutrons for Cultural Heritage Studies, Grenoble, France, 8-12 October.

Quasicrystals - the Silver Jubilee, Tel Aviv, Israel, 14-19 October. MSA-GS-ANL Short Course on 'Amphiboles', Rome, Italy, 29-31 October.

Eighth Asian Crystallographic Association Conference (AsCA '07), Taipei, 4-7 November.

The Executive Committee met in Salt Lake City, USA, in July. The Finance Committee met in Grenoble, France, in March, and in Salt Lake City to prepare its advice and recommendations on finances, establishment and staff matters. The most important items of business dealt with by the Executive Committee at its meeting, and in e-mail ballots, were:

editorial policy, pricing policy and subscription rates, consideration of appointment of new Editors for Acta Cryst. Sections C, E and $\mathrm{F}$ and Journal of Applied Crystallography, approval of appointments of Co-editors, electronic publishing, archival policy, Special Issues, open access, alternative financial models for Acta $E / F$, education papers, language improvement of submitted papers, and other matters concerning the IUCr journals;

approval of launch of Acta Cryst. Section E as a fully open-access journal;

review of contract with Wiley-Blackwell (formerly BlackwellMunksgaard);

approval of audited accounts for the previous year;

amendments to Statutes and By-Laws;

review of proposed revision to ICSU dues structure;

General Fund estimates and level of unit contribution;

status of membership subscriptions;

Joint National or Regional Committees for Crystallography;

investment policy;

funding and uses of Publications and Journals Development Fund and Research and Education Fund;

closure of Book Fund and establishment of General Assembly and

Congress Fund;

sponsorship and financial support for meetings, young scientists' support;

Journal Grants Fund;

cooperation with databases, policy concerning availability of deposited CIFs;

progress with Volumes A, A1, B, C, D, E, F and G of International Tables and development of associated software, appointments of new Editors for Volumes A and F, development work to make International Tables available online; review of contract with Springer; IUCr Newsletter; 
World Database of Crystallographers; Online Dictionary of Crystallography; promotional activities; 60th anniversary of the IUCr;

Ewald Prize;

discussion of arrangements for Osaka Congress; nomination procedures.

Other items dealt with in this way were:

uses of the Crystallographic Information File (CIF), work of the Committee for the Maintenance of the CIF Standard (COMCIFS), provision of checking services to other publishers, chemical information, support of $\mathrm{mmCIF}$ project and CIF handling software;

consideration of publications, jointly with Oxford University Press, in the IUCr/OUP Book Series;

crystallography in Africa;

Visiting Professorship scheme;

review of activities of Commissions;

proposal for new Commission;

review of activities of Regional Associates;

review of reports of IUCr Representatives on other bodies;

review of report of Committee on Crystallographic Databases.

Items concerning the Chester office were:

staffing requirements in the IUCr office in Chester;

risk analysis;

upgrading of office technology, provision of internet services.

\section{Publications}

Volume 63 of Acta Crystallographica, Volume 40 of Journal of Applied Crystallography and Volume 14 of Journal of Synchrotron Radiation were published.

\section{Adhering Bodies}

A list of Adhering Bodies of the Union, with names and addresses of the Secretaries of the National Committees for Crystallography, was published as Annex IV to the Report of the Twentieth General Assembly and International Congress of Crystallography [Acta Cryst. (2006), A62, 465-526].

\section{Work of the Commissions}

\subsection{Commission on Journals}

4.1.1. Overview. The total number of articles published in $\mathrm{IUCr}$ Journals in 2007 was 6637, which compares with 5376 in 2006 and 4324 in 2005 . The number of pages published, however, was lower (16138 compared with 17524 pages in 2006 and 14869 pages in 2005); this decrease is a result of a change to a new short-format style for Section E. Of the total, 10170 pages were published online only.

In 2007, 510 pages were printed for Acta Crystallographica Section A (528 in 2006), 940 for Section B (1138 in 2006), 1510 for Section C (1450 in 2006) and 1283 for Section D (1571 in 2006). Section E published 8375 electronic only pages (9843 in 2006) and Section F published 1090 electronic only pages (1300 in 2006).

The average length of Full Articles was 9.1 pages for Section A, 8.9 pages for Section B, 3.4 pages for Section C, 9.1 pages for Section D, 1.6 pages for Section $\mathrm{E}$ and 3.9 pages for Section F. Average publication times were as follows: Section A 5.3 months, Section B 5.8 months, Section C 2.1 months, Section D 4.4 months, Section E 0.8 months and Section F 2.4 months. The rejection/withdrawal rates were: Section A $32 \%$, Section B $40 \%$, Section C 52\%, Section D $23 \%$, Section E $17 \%$ and Section F 10\%.

The number of Full Articles published in Journal of Applied Crystallography (JAC) in 2007 was 124 (89 in 2006). The number of pages increased from 928 to 1895 as a result of the publication of the SAS 2006 Proceedings. The average review time was 4.3 months and the technical-editing time 2.0 months; the overall publication time was 6.3 months. The rejection/withdrawal rate was $24 \%$.

The number of Full Articles published in Journal of Synchrotron Radiation (JSR) in 2007 was 64 (58 in 2006). The number of pages increased to 535 in 2007 (496 in 2006). The average review time was 3.5 months and the technical-editing time 1.5 months; the overall publication time was 5.0 months. The rejection/withdrawal rate was $22 \%$.

A survey of the contents of IUCr journals is presented in Table 1. IUCr journals continue to be highly ranked amongst crystallographic journals; JAC had the highest impact factor at 2.5.

Proceedings of the XIIIth International Conference on SmallAngle Scattering (SAS 2006) were published in $J A C$, Proceedings of the CCP4 Study Weekend on Crystallography of Complexes were published in Section D and the 23rd ECM Abstracts were published in Section A. JSR published a themed issue on Radiation Damage in Macromolecules.

The hybrid open-access option introduced for authors in 2004 has become increasingly popular, and during the year work was carried out to prepare for Section $\mathrm{E}$ to become a full open-access journal from 2008. Work has also been continuing on streamlining procedures for Section F. A tool that will create experimental tables for inclusion in manuscripts from mmCIF files was made available. Section Editors of Section F were strongly involved in updating publication standards for NMR-based structures.

The Commission held two informal meetings - at the ACA meeting in Salt Lake City, USA, and at ECM-24 in Marrakech, Morocco.

At the end of the year, more than 150 Section Editors and Coeditors worked on IUCr journals, with allocated papers ranging from 1 to 433. The work of all these dedicated colleagues and of the competent and equally dedicated staff at Chester is essential to the wellbeing of the journals and highly appreciated.

\section{G. Kostorz, Chair}

4.1.2. Acta Crystallographica Section A. Section A published 510 pages in 2007, slightly down from 528 in 2006 (and down from 622 in 2005). In addition, the Abstracts of ECM-24 in Marrakech, Morocco, comprise 293 pages. All six issues were regular ones. The number of pages devoted to research topics (Research Papers, Short Communications and two Letters to the Editor) was 440 pages (447 in 2006, down from 531 in 2005). The average number of pages per regular issue was 73 in 2007 ( 70 for the 5 issues of 2006). The average publication time for regular papers increased from 5.0 to 5.3 months, due to an increase in the average review time of 0.7 months to 3.8 months balanced by a decrease in the average editing time of 0.4 months.

There were 47 full Research Papers (43 in 2006), including a Lead Article by F. Livet, giving an average of 9.1 pages per article, down from 10.1 pages in 2006. There were 3 Short Communications, and 2 Letters to the Editor resolving a prolonged discussion. The proportion of withdrawn and rejected manuscripts remained nearly unchanged at $32 \%$. All these numbers show little change from last year, indicating that the shrinking trend of Section A has levelled off. 
However, the warning lights are still on with some issues being rather slim; a preoccupying minimum of only 4 regular papers has been reached in November. There is no backlog in the editorial offices; I wish there was.

Section A is a high-level journal with a diverse range of topics. About $40 \%$ of the papers may be classified as mathematical (including group theory, twinning, topology and crystal chemistry). Other topics are diffraction and new phasing methods, some relating to single-particle imaging. Typical crystallographic topics such as crystal structure determination and charge densities, but also diffuse scattering, electron crystallography and electron microscopy, move increasingly from theory to applications and become less prominent in Section A. The geographical distribution of the origins of the articles (counted as integral or half-integral numbers) is Europe 57\% $(-4)$, the Americas 19\% (-8) and Asia+Australia 24\% (+12). The impact factor is 1.68, somewhat lower than in 2005 (1.79) and 2004 (1.83) but higher than in 2002 and 2003. Section A competes with physics journals, such as Ultramicroscopy, rather than with chemistryoriented journals publishing crystal structures. I thank the Co-editors for their often difficult work. I am sorry that E. Weckert has retired, and glad that $\mathrm{H}$. Zimmermann replaces him. Thanks are also due to the Chester editorial staff.

In the pipeline for 2008 is the Special Anniversary Issue (January 2008). The Special Issue on Phase Transitions II commissioned by Guest Editor D. Pandey figures still among the promises. A Lead Article on crystallization techniques is expected for May or July 2008, and other prospective authors are on the wish list.

\section{Schwarzenbach, Editor of Section A}

4.1.3. Acta Crystallographica Section B. The number of pages printed for Section B decreased from a record high of 1138 in 2006 to 940 in 2007. The average length of papers also decreased slightly from 9.3 to 8.9 pages. One Feature Article was published in 2007 .

The strength of Section B is in the quality and durability of the articles it publishes rather than in their immediate impact. All those connected with the journal are very pleased with the quality of the papers being published. Several papers reporting structures of more than 15 different compounds have appeared. Multi-temperature studies, e.g., of phase transitions, have included refinements at a large number of temperatures. Studies of single-crystal photochemical reactions have included full refinements for many different degrees of conversion of reactants to products.

There has been a slight decrease in time to publication in the last year (6.3 to 5.8 months). The fraction of manuscripts withdrawn or rejected increased in 2007, in line with higher submission rates during 2006 and the start of 2007. The impact factor of the journal increased from 1.9 to 2.2 .

During 2007 Co-editor L. A. Aslanov retired after 11 years on the board. We thank him for his fine service. We also thank the Chester editorial staff, and especially Jill Bradshaw, for all they do to help authors with their manuscripts and to produce a quality journal. Anybody turning the pages of Section B or looking at the web version can quickly see that it has been put together carefully by people who are skilled copy editors and who know how to make pages visually attractive.

\section{P. Brock, Editor of Section B}

4.1.4. Acta Crystallographica Section C. Section C continues to specialize in the rapid publication of high-quality studies of novel and challenging crystal and molecular structures. In 2007, Section C published 451 papers (44 inorganic, 191 metal-organic and 216 organic) in a total of 1510 pages. The proportions of inorganic $(10 \%)$ and metal-organic (43\%) papers increased slightly, while the proportion of organic papers (47\%) decreased slightly in comparison with 2006. The citation impact factor has risen from 0.78 in 2005 to 0.90 in 2007.

Publication times in 2007 have not changed this past year with the majority of technically correct and well written papers appearing online (http://journals.iucr.org/c) within two months of submission. After review some $52 \%$ of submissions to Section $\mathrm{C}$ in the past year were either subsequently withdrawn by the authors or rejected - a $2 \%$ increase over 2006.

C. Glidewell has resigned from being Deputy Editor but will continue as a valued Co-editor; it is a great pleasure to thank him warmly for his help and wise advice over the last eight years. A. Linden will be taking over from me as Editor of Section C in August 2008 and following Dr Glidewell's suggestion has been appointed Deputy Editor until then. I am also grateful for the assistance of A. Linden and that of the Chester editorial staff in the review of the latest Section C Notes for Authors. I would like to take this opportunity to thank all the Section C Co-editors and the Chester editorial office staff for their outstanding contributions to Section $\mathrm{C}$ and for the assistance they have given me since I was appointed Section Editor in 1999.

\section{G. Ferguson, Editor of Section C}

4.1.5. Acta Crystallographica Section D. The past year has been an interesting one for Section D - one that has raised some concerns, but which has also highlighted the important role that the journal plays for the biological crystallography community. One Special Issue (the annual CCP4 issue) was published, together with 11 regular monthly issues. Of some concern, both the number of articles (157) and the number of pages (1283) showed a decline from 2006, where the corresponding numbers were 191 and 1571, respectively. As in previous years, most of the articles were full articles (128), but the proportion of these that were methodological in content appeared to be somewhat reduced; about $35 \%$ compared with $52 \%$ in 2006 . It is difficult to know whether there is any indication of a longer-term trend here, however, as 2006 was marked by the publication of three Special Issues, all focused on methods.

A feature of 2007 was the increased number of contributions to Section D that raised issues of crystallographic practice and policy. These included an editorial on 'numerology' (numerical significance in crystallography), a commentary from G. Kleywegt on model optimization and validation, a series of letters on stereochemical restraints in refinement, a letter from A. Wlodawer on data deposition, and a feature article by $\mathrm{Z}$. Dauter on handedness and phasing by anomalous scattering. Together with a thoughtful essay by C. AbadZapatero, these contributions point to the role Section D can play as a stimulus for thinking about policy and practice. Such questions are becoming increasingly important as many researchers, not trained in crystallography, use the increasingly automated tools that are now available.

The CCP4 Special Issue in January 2007 was focused on the Crystallography of Complexes. This is one of the most important areas for the future as we seek to understand macromolecular interactions that are often transient in nature. It brings crystallography into partnership with a great variety of other biophysical and structural approaches and points to further innovation in our field. It also strongly connects with structure-based drug design and the pharmacological use of crystallography. We thank T. Skarzynski 
Table 1

Survey of the contents of IUCr journals.

Acta Crystallographica

\begin{tabular}{|c|c|c|c|c|c|c|c|c|c|c|c|c|c|}
\hline \multirow[b]{2}{*}{ Vol. } & \multirow[b]{2}{*}{ Year } & \multirow{2}{*}{\multicolumn{2}{|c|}{$\begin{array}{l}\text { Number } \\
\text { of pages§ }\end{array}$}} & \multirow{2}{*}{\multicolumn{2}{|c|}{$\begin{array}{l}\text { Number } \\
\text { of papers }\end{array}$}} & \multicolumn{4}{|c|}{ Full Articles $\dagger$} & \multicolumn{4}{|c|}{$\begin{array}{l}\text { Short } \\
\text { Communications } \ddagger\end{array}$} \\
\hline & & & & & & Numb & & $\begin{array}{l}\text { Avera } \\
\text { length }\end{array}$ & & $\mathrm{Nu}$ & ber & $\begin{array}{l}\text { Aver } \\
\text { lengt }\end{array}$ & $\begin{array}{l}\text { rage } \\
\text { th }\end{array}$ \\
\hline A59 & \multirow{5}{*}{2003} & 628 & \multirow{5}{*}{8735} & \multicolumn{2}{|l|}{83} & & \multicolumn{2}{|l|}{7.91} & \multicolumn{2}{|l|}{25} & \multicolumn{2}{|l|}{8.8} \\
\hline B59 & & 821 & & 88 & & $81\}$ & & $9.8\}$ & & 7 & & 2.1 & \\
\hline C59 & & 1482 & & 482 & 2424 & 478 & 568 & 2.8 & 6.1 & 4 & 81 & 2.2 & 4.7 \\
\hline D59 & & 2385 & & 466 & & $429\}$ & & $5.2\}$ & & 37 & & 3.4 & \\
\hline E59 & & 3419 & & 1305 & & 1297 & & 2.5 & & 8 & & 1.8 & \\
\hline A60 & & 644 & & 96 & & 78 & & 7.8 & & 18 & & 2.0 & \\
\hline $\mathrm{B} 60$ & & 763 & & 87 & & 84 & & $8.9\}$ & & 3 & & 3.3 & 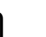 \\
\hline C60 & 2004 & 1694 & 10183 & 556 & 3061 & 554 & 624 & 3.0 & 5.8 & 2 & 80 & 4.0 & 2.7 \\
\hline D60 & & 2406 & & 511 & & $462\}$ & & $4.9\}$ & & 49 & & 3.0 & \\
\hline E60 & & 4676 & & 1811 & & 1803 & & $2.6^{\circ}$ & & 8 & & 1.6 & \\
\hline A61 & & 622 & & 74 & & 55 & & 9.21 & & 19 & & 6.1 & \\
\hline B61 & & 730 & & 87 & & $84\}$ & & $8.5\}$ & & 3 & & 3.0 & \\
\hline C61 & & 1412 & & 439 & & 437 & & 3.2 & & 2 & & 4.0 & \\
\hline D61 & 2005 & 1681 & 12986 & 233 & 4031 & $200\}$ & 648 & $7.8\}$ & 6.0 & 33 & 66 & 3.8 & 4.1 \\
\hline E61 & & 7439 & & 2887 & & 2880 & & 2.6 & & 7 & & 1.1 & \\
\hline F61 & & 1102 & & 311 & & $309\}$ & & $3.5\}$ & & 2 & & 3.0 & \\
\hline A62 & & 528 & & 58 & & 43 & & 10.1 & & 15 & & 6.2 & \\
\hline B62 & & 1138 & & 127 & & 119 & & $9.3\}$ & & 8 & & 3.1 & \\
\hline C62 & & 1450 & & 447 & & 446 & & 3.3 & & 1 & & 8.0 & \\
\hline D62 & 2006 & 1571 & 15830 & 191 & 5159 & $178\}$ & 678 & $8.6\}$ & 6.4 & 13 & 57 & 3.5 & 3.6 \\
\hline E62 & & 9843 & & 3991 & & 3978 & & 2.5 & & 13 & & 1.7 & \\
\hline F62 & & 1300 & & 345 & & $338\}$ & & $3.8\}$ & & 7 & & 1.6 & \\
\hline A63 & & 510 & & 66 & & 47 & & 9.1 & & 19 & & 4.4 & \\
\hline B63 & & 940 & & 110 & & $102\}$ & & $8.9\}$ & & 8 & & 3.4 & \\
\hline C63 & & 1510 & & 451 & & 449 & & 3.4 & & 2 & & 2.5 & \\
\hline D63 & 2007 & 1283 & 13708 & 157 & 6247 & $128\}$ & 555 & $9.1\}$ & 6.4 & 29 & 78 & 4.0 & 3.2 \\
\hline E63 & & 8375 & & 5181 & & 5165 & & 1.6 & & 16 & & 1.7 & \\
\hline F63 & & 1090 & & 282 & & $278\}$ & & $3.9\}$ & & 4 & & 2.0 & \\
\hline
\end{tabular}

Journal of Applied Crystallography

\begin{tabular}{|c|c|c|c|c|c|c|c|c|c|}
\hline \multirow[b]{2}{*}{ Vol. } & \multirow[b]{2}{*}{ Year } & \multirow[b]{2}{*}{$\begin{array}{l}\text { Number } \\
\text { of pages§ }\end{array}$} & \multirow[b]{2}{*}{$\begin{array}{l}\text { Number } \\
\text { of papers }\end{array}$} & \multicolumn{2}{|c|}{ Full Articles $\dagger \dagger$} & \multicolumn{2}{|c|}{$\begin{array}{l}\text { Short } \\
\text { Communicationst+ }\end{array}$} & \multicolumn{2}{|c|}{ Short items $\S$} \\
\hline & & & & Number & $\begin{array}{l}\text { Average } \\
\text { length }\end{array}$ & Number & $\begin{array}{l}\text { Average } \\
\text { length }\end{array}$ & Number & $\begin{array}{l}\text { Average } \\
\text { length }\end{array}$ \\
\hline 36 & 2003 & 1505 & 282 & 225 & 5.9 & 26 & 3.8 & 31 & 1.7 \\
\hline 37 & 2004 & 1041 & 170 & 110 & 7.7 & 27 & 4.0 & 33 & 2.3 \\
\hline 38 & 2005 & 1045 & 157 & 111 & 7.8 & 24 & 4.4 & 22 & 2.4 \\
\hline 39 & 2006 & 928 & 140 & 89 & 8.1 & 36 & 4.2 & 15 & 2.5 \\
\hline 40 & 2007 & 1895 & 314 & 124 & 8.1 & 172 & 4.8 & 18 & 3.1 \\
\hline
\end{tabular}

Journal of Synchrotron Radiation

\begin{tabular}{|c|c|c|c|c|c|c|c|c|c|}
\hline \multirow[b]{2}{*}{ Vol. } & \multirow[b]{2}{*}{ Year } & \multirow[b]{2}{*}{$\begin{array}{l}\text { Number } \\
\text { of pages§ }\end{array}$} & \multirow[b]{2}{*}{$\begin{array}{l}\text { Number } \\
\text { of papers }\end{array}$} & \multicolumn{2}{|c|}{ Full Articles } & \multicolumn{2}{|c|}{$\begin{array}{l}\text { Short } \\
\text { Communications }\end{array}$} & \multicolumn{2}{|c|}{ Short items $\S \S$} \\
\hline & & & & Number & $\begin{array}{l}\text { Average } \\
\text { length }\end{array}$ & Number & $\begin{array}{l}\text { Average } \\
\text { length }\end{array}$ & Number & $\begin{array}{l}\text { Average } \\
\text { length }\end{array}$ \\
\hline 10 & 2003 & 475 & 108 & 77 & 5.5 & 5 & 2.2 & 26 & 0.8 \\
\hline 11 & 2004 & 512 & 119 & 85 & 5.5 & 3 & 3.3 & 31 & 1.0 \\
\hline 12 & 2005 & 838 & 136 & 115 & 6.8 & 5 & 3.4 & 16 & 1.9 \\
\hline 13 & 2006 & 496 & 77 & 58 & 7.6 & 7 & 3.4 & 12 & 1.8 \\
\hline 14 & 2007 & 535 & 76 & 64 & 7.8 & 2 & 2.0 & 10 & 2.6 \\
\hline
\end{tabular}

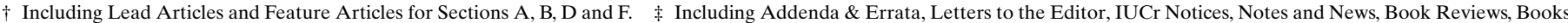

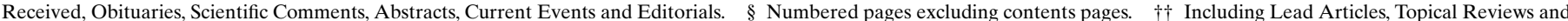

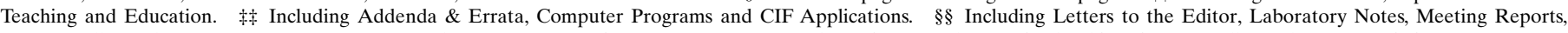

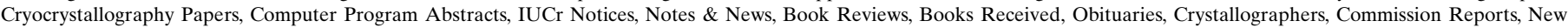
Products, Abstracts, Current Events and Editorials.

and A. McCoy very much for their Guest Editorship of this Special Issue.

There continue to be some 'grey areas' between Section D and Section F, mostly around crystallization papers that are submitted as possible methods papers. Such cases are easily sorted out between the Editors of the two journals. The electronic submission system continues to work very well, though we have noticed an increasing difficulty in finding suitable and willing referees. This is a problem 
that is common to other journals, and we have to think about new approaches. Publication times are good, at an average of 4.4 months for full articles. The publication quality is outstanding, for which we thank the Chester office, and we are extremely grateful to Louise Jones and Simon Glynn in Chester for their superb support and advice.

\section{E. N. Baker and Z. Dauter, Editors of Section D}

4.1.6. Acta Crystallographica Section E. The year 2007 has seen yet another sustained period of growth for Section E and the implementation of significant new procedures.

The number of papers submitted was 6454 , an increase of $26 \%$ over the 2006 figure. The total number of papers published was 5181 , compared with 3991 in 2006, an increase of $30 \%$. Of these, $61 \%$ described organic, $36 \%$ metal-organic and 3\% inorganic structures. $49 \%$ of papers had the main correspondence author in the People's Republic of China, $8 \%$ in India, $6 \%$ in the USA, $5 \%$ in Germany, $4 \%$ in the UK, $3 \%$ in Malaysia, $3 \%$ in Turkey and smaller percentages in other countries. During 2007 authors from 75 countries published in Section E. The change to the new short-format system early in 2007 has resulted in a significantly shorter average length for published articles (1.6 instead of 2.5 pages) and a small reduction in the average time from submission to publication (from 0.9 to 0.8 months). The journal's impact factor remained almost unchanged, at 0.567 .

Early in 2007 a new group of Co-editors was enlisted. However, during the year S. Ohba and M. R. M. da Silva retired. We thank them for their contribution to the success of the journal. There are now 58 Co-editors, including the two joint Section Editors.

A year ago, we described in detail the new short format to be adopted; this became operational in March 2007. We are grateful to the editorial and development staff in Chester for their efforts in bringing this innovation to fruition on time. One result has been a significant easing of the workload on our Co-editors.

In our annual report for 2006, the views of the IUCr Executive Committee and Finance Committee were noted in respect of the financial viability of the journal. In fact, the Executive Committee decided to move the journal's operation and distribution from a subscription basis to an open-access model - the first journal of the IUCr to take this step. The new system came into force in December 2007. The intention was to keep the open-access fee, charged to most authors, as low as possible. This has been achieved successfully, with a standard fee of only USD 150, when the open-access charges of most scientific journals for full research papers are in the thousands of dollars. The resulting combination of free access to the journal for all readers, a low charge to authors, a range of generous discounts from the standard fee and waivers for authors from some countries, and the high quality of the complete publication package provided by the journal is proving very attractive, and the drying up of submissions predicted by some observers following this major change has not occurred: over 100 papers were submitted in the first three weeks of 2008 , equivalent to an annual rate approaching half of that reached in 2006 when there were no charges to authors and the journal was using the previous longer format. [The present submission rate is about $75 \%$ of pre-2008 figures.] For full information on the open-access mechanism, including available discounts, see the journal web site at http://journals.iucr.org/e/journalhomepage.html.

Finally we again thank the editorial staff in the Chester office for all their help and dedication. In particular, we are indebted to Gillian Holmes, Sean Conway, Sarah Froggatt and Lisa Stephenson who look after Section E on a daily basis, and to Mike Hoyland, David Hoare and David Holden who have been particularly involved in the development of new procedures under the direction of Peter Strickland. We are also grateful to those Section C Co-editors who helped us cope with the huge load of submissions prior to the introduction of open access - a staggering 785 and 1066 papers were submitted in the months of October and November, respectively!

\section{W. Clegg and D. G. Watson, Editors of Section E}

4.1.7. Acta Crystallographica Section F. The third year of publication of Section $\mathrm{F}$ saw the journal mature into its role as the home for the rapid publication of structure and crystallization communications on biological macromolecules. In 2007 the number of articles published was 282 and the number of pages published was 1090 . The average time from submission to publication, including peer review, of 2.4 months remained fast.

Online tools to allow authors to create experimental tables for inclusion in manuscripts from mmCIF files were made available and provide a streamlined route from database to publication.

The Editors have been keen to maintain scientific standards in the journal and in 2007 were instrumental in providing updated standards for publication of NMR structures in IUCr journals.

\section{H. M. Einspahr and J. M. Guss, Editors of Section F}

4.1.8. Journal of Applied Crystallography. The number of Full Articles published in $J A C$ in 2007 was 124 (89 in 2006). The number of pages increased from 928 to 1895; this increase was mainly due to the publication (electronic version only) of articles from the SAS 2006 meeting, held in Kyoto, Japan, in July 2006.

The number of manuscripts submitted was 258, compared with 399 in 2006 (when the numbers were boosted by submissions for the SAS 2006 Proceedings) and 196 in 2005. The impact factor remained high at 2.5 .

Online submission is now almost exclusively used and the system works well. The publication time increased slightly to 6.6 months (4.6 months for editors/reviewers and 2.0 months for production). The average review time decreased to 4.3 months and the technicalediting time remained the same at 2.0 months; the overall publication time decreased to 6.3 months. The average publication time for Short Communications (including SAS 2006 papers) was 4.8 months. The rapid publication of the SAS 2006 Proceedings was achieved by putting the articles online as soon as they were ready for publication.

The year saw the retirement of G. Kostorz as Editor after eight years of service and the appointment of A. Pyzalla as new Editor in mid-2007. It has again been a great pleasure to interact with the Chester staff who handled all matters arising with great competence and kindness.

\section{A. Pyzalla, Editor of JAC}

4.1.9. Journal of Synchrotron Radiation. In 2007, JSR published 64 articles and a total of 535 pages in the six issues. This was an increase in both articles and pages as compared to 2006, due primarily to a large Special Issue. This Special Issue on Radiation Damage was published in January (Volume 14 Part 1), with E. Garman and S. McSweeney serving as Guest Editors. We continue to believe that the publication of selected papers from workshops in such Special Issues is an important service to the synchrotron-radiation community and we plan to continue this policy in the future.

The Facility Information pages also continued in 2007. One page per issue is devoted to each of the three third-generation hard X-ray sources (APS, ESRF and SPring-8); these pages provide an oppor- 
tunity for the facilities to communicate important news and updates to the international community of synchrotron-radiation users.

We are happy to report that the average review time for 2007 was reduced from 4.8 months in 2006 to 3.5 months and that the average editing time was reduced from 1.7 months in 2006 to 1.5 months in 2007 resulting in an average publication time of 5.0 months. In addition, the impact factor remained high at 2.4.

A. Kvick, D. M. Mills and T. Ohta, Editors of JSR

\subsection{Commission on International Tables}

International Tables for Crystallography is available as eight separate print volumes and, since April 2007, as the full set of all eight volumes as pdfs on SpringerLink and as full-text html and pdfs on the International Tables Online web site (http://it.iucr.org) developed by the IUCr.

The first edition of International Tables Online has so far been bought by a large number of consortia and institutions across the world and reviews have been very favourable. The print volumes have also continued to sell well: 281 copies of Volume A (SpaceGroup Symmetry, Fifth Edition, edited by Th. Hahn), 100 copies of Volume A1 (Symmetry Relations between Space Groups, First Edition, edited by H. Wondratschek and U. Müller), 96 copies of Volume B (Reciprocal Space, Second Edition, edited by U. Shmueli), 110 copies of Volume C (Mathematical, Physical and Chemical Tables, Third Edition, edited by E. Prince), 103 copies of Volume D (Physical Properties of Crystals, First Edition, edited by A. Authier), 67 copies of Volume E (Subperiodic Groups, First Edition, edited by V. Kopský and D. B. Litvin), 119 copies of Volume F (Crystallography of Biological Macromolecules, First Edition, edited by M. G. Rossmann and E. Arnold) and 76 copies of Volume G (Definition and Exchange of Crystallographic Data, First Edition, edited by S. R. Hall and B. McMahon) were sold during 2007. In addition, 292 copies of the Brief Teaching Edition of Volume A were sold.

Revisions of several of the volumes and the further development of International Tables Online are planned. Th. Hahn retired as Editor of Volume A in 2007. All members of the Commission would like to express their deep gratitude to him for the extraordinary amount of time and work he has devoted to International Tables over the last 45 years. He has been succeeded as Editor of Volume A by M. I. Aroyo, who will work on the preparation of the Sixth Edition of Volume A. Work on the Third Edition of Volume B has progressed well and the volume is expected to go to press during summer 2008. The volume will include a new chapter on modern extensions of the Ewald method for Coulomb interactions in crystals and three new sections on electron diffraction and electron microscopy in structure determination, three-dimensional reconstruction, and single-particle reconstruction. Chapters on methods of structure determination have been extensively revised and many other chapters have been revised and updated. The second edition of Volume A1 is expected to go to press in 2009. It will include two new chapters: one describing how to create trees of group-subgroup relations and one on the Bilbao Crystallographic Server. Two new sections to the tables and graphs that extend the treatment of the supergroups of space groups and a new section on supergroups are also planned. The presentation of the subgroup data for isomorphic subgroups in the tables will be homogenized. D. Himmel has joined E. Arnold and M. G. Rossmann as Editors for the Second Edition of Volume F, which is now in an advanced stage of planning. Most of the existing chapters will be updated and many new chapters will be commissioned. The Second
Edition is expected to be published in 2010. H. Fuess continues to plan the Fourth Edition of Volume C. A publication date is not yet known. In addition, significant enhancements to International Tables Online are planned, including the addition of a symmetry database that will provide far more symmetry information to the user than is contained in the printed volumes.

Further information about the volumes can be found at the home page of the Commission, http://www.iucr.org/iucr/commissions/ commit.html.

\section{H. Fuess, Chair}

\subsection{Commission on Aperiodic Crystals}

The Commission has continued actively to promote aperiodic crystallography in 2007, in organizing meetings and workshops as well as in coordinating activities of and between the quasi-crystalline and incommensurate structure communities.

As part of these activities, the Commission continued to promote aperiodic crystallography at national, regional and international meetings. During 2007, two very successful meetings in the area of aperiodic crystallography were held: (i) the Fifth Workshop on the Structural Analysis of Aperiodic Crystals, Bayreuth, Germany, 1-4 March, organized by S. van Smaalen and (ii) 'Quasicrystals - The Silver Jubilee', Tel Aviv, Israel, 14-19 October, organized by R. Lifshitz, D. Shechtman and S. Ben Abraham.

Two important new books on aperiodic crystallography were published by long-standing members of the community in 2007: (i) Aperiodic Crystals from Modulated Phases to Quasicrystals by T. Janssen, G. Chapuis and M. de Boissieu and (ii) Incommensurate Crystallography by S. van Smaalen. Both books are published by Oxford University Press as IUCr Monographs on Crystallography (Nos. 20 and 21, respectively). Both are highly recommended.

Very important upcoming meetings for the Commission in 2008 include (i) the Osaka Congress and (ii) the 10th International Conference on Quasicrystals, ICQ10, Zürich, Switzerland, 6-11 July 2008. Planning for both meetings is well advanced. There will be two Keynote Lectures and four separate Microsymposia in the area of aperiodic crystallography at the Osaka Congress, which the Commission has helped organize.

The Commission maintains internet pages at the web site of the IUCr at http://www.iucr.org/iucr/commissions/cac.html. A web site on all aspects of the crystallography of aperiodic crystals is maintained by the Special Interest Group (SIG) on Aperiodic Crystals of the European Crystallographic Association. It is maintained by M. Dusek (Prague, Czech Republic), and can be found at http://www-xray. fzu.cz/sgip/aphome.html.

\section{R. Withers, Chair}

\subsection{Commission on Biological Macromolecules}

The Commission has continued to support the vitality of the biological crystallography community, particularly through recommending and supporting IUCr proposals to hold meetings, workshops and schools. The Commission is also working with various groups within the community to coordinate with the Protein Data Bank (PDB) updated guidelines for structure deposition. The PDB has now implemented the requirement for uniform structure-factor deposition.

A key activity of the Commission was contributing to the planning of the Osaka Congress. Structural biology will be represented at all 
levels, with the revelation of spectacular novel macromolecular structures and evolving methods described in Plenary Lectures, invited presentations, topical sessions and posters. A large number of students will attend and participate from all corners of the world and the travel of many young scientists will be sponsored by the IUCr. Three members of the Commission (E. Arnold, A. Podjarny and T. Tsukihara) met with the International Programme Committee to develop suggestions for Plenary Lectures, Keynote Lectures, topicoriented Microsymposia and Chairs for all of the suggestions. The programme has been developed and refined based on speaker acceptance from invitation and abstract submission - the Osaka Congress programme promises to be exciting and action packed.

Regional meetings with biologically relevant content sponsored by the IUCr in 2007 included: in April the RapiData course (Brookhaven, USA); in June a workshop on Crystallization of Membrane Proteins (Brookhaven, USA); in July the Annual Meeting of the American Crystallographic Association (Salt Lake City, USA); in August the 13th International Summer School on Crystal Growth (Park City, USA), the 9th International Biology and Synchrotron Radiation Conference (Manchester, UK), and ECM-24 (Marrakech, Morocco); in September a Symposium honouring Professor Dame Louise Johnson (Oxford, UK), and Electron Microscopy and Multiscale Modeling (Moscow, Russia); and in November the 8th Asian Crystallographic Association Conference (Taipei). These meetings, schools and workshops provide tremendous value in training in and dissemination of novel scientific methods.

Upcoming activities for the Commission include appointment of new members and Chair. A related activity is the development of a second edition of International Tables for Crystallography, Volume F, Crystallography of Biological Macromolecules, edited by E. Arnold, M. G. Rossmann and D. M. Himmel, which should be ready by 2010 . Additional schools and meetings will be sponsored by the IUCr to help in disseminating crystallographic knowledge in the most effective ways to deserving bodies of students.

\section{E. Arnold, Chair}

\subsection{Commission on Charge, Spin and Momentum Densities}

The Sagamore meeting, the Gordon Research Conference (GRC), the European Charge Density Meeting (ECDM) and the Inelastic X-ray Scattering Meeting (IXS) are the major conferences of the community. During 2007, there was a GRC meeting entitled Electron Distribution and Chemical Bonding - Dynamics and Densities, Mount Holyoke College, South Hadley, USA, 1-6 July 2007, organized by C. Gatti and D. Jayatilaka; in September there was an X-ray Diffraction workshop in Italy organized by P. Macchi.

The 6th International Conference on Inelastic X-ray Scattering (IXS 2007) was held on Awaji Island, Hyogo, Japan, 5-11 May 2007. This conference is held every three years, providing a forum for presenting the latest results and exchanging ideas on scientific applications and technical developments in the IXS field. IXS covers a diverse group of techniques using synchrotron radiation, including electronic resonant and non-resonant scattering, the meV-resolved method, the nuclear resonant method, and Compton scattering. IXS 2007 was a success, with 115 participants from 53 institutions in 11 countries worldwide. The number of overseas participants was 56, from Canada (2), Finland (5), France (13), Germany (2), India (3), Italy (5), Netherlands (2), Taiwan (3), UK (2) and USA (19). Eighteen of the participants were students, many from overseas, demonstrating that the IXS community is flourishing.
The programme of IXS 2007 was composed of a welcome and general overview session, technique-based overview sessions, scientifically focused sessions, and a conference summary and closing session. The scientifically focused sessions addressed topics on WaterRelated Physics; Strongly Correlated Electrons; Lattice and Vibrational Dynamics; New Scientific Frontiers in IXS; Raman Scattering and Theory; Basic Physics of Electronic Structures; and New Techniques and Future X-ray Sources. The programme included 3 plenary talks, 29 invited talks, 4 oral contributions and 69 poster presentations.

The GRC meeting started with a session on the topic of 'Where are we now, Where are we going' on the evening of 1 July. For the remaining four days, the topics covered were: Time-Resolved Spectroscopy, Structure and Bonding: the Present and the Future; HighThroughput or Quality: Alternative Paths for X-ray Diffraction; New Techniques and Tools for Structure, Bonding and Properties in Biology; Toward Charge Densities for Proteins: Which Database to Use? Will Biologists Care?; Progresses in Electron Diffraction; Chemical Concepts from Electron Density: Theory vs Experiment; and Densities, Density Matrices and Wavefunctions, which was dedicated to V. H. Smith Jr. In addition, there were two afternoon poster sessions organized by D. Jayatilaka. The meeting was well attended (98) by senior and junior scientists, lectures were given in the right order and the discussions were truly beneficial. The next meeting planned will be in 2010 , organized by D. Jayatilaka.

During August, 2007 the European Crystallographic Meeting was held in Marrakech, Morocco; special sessions in the charge density field were organized by L. J. Farrugia and P. Macchi.

Yu Wang, Chair

\subsection{Commission on Crystal Growth and Characterization of Materials}

The year 2007 was busy for the Commission. Two meetings of the Commission members and consultants were held. The first was during the 15th International Conference on Crystal Growth in Salt Lake City, USA, in August (http://www.crystalgrowth.us/iccg15/index.php) and was attended by D. F. Bliss, H. A. Dabkowska, T. Duffar, R. Fornari, K. Kakimoto, A. Moreno, T. Ohachi, A. Pajaczkowska, P. Rudolph and E. Vlieg. The guest of honour was A. A. Chernov (USA) - recently elected the Chair of the International Organization for Crystal Growth (IOCG). The second meeting took place in October in St Petersburg, Russia, during the II International Conference 'Crystallogenesis and Mineralogy' (http:///www. minsoc.ru/km2007). This was attended by H. A. Dabkowska, J. M. Garcia-Ruiz, A. Voloshin and J. Wang. The guest of honour was H. Klapper - a former Chair of this Commission.

The main concern at both meetings was the call for future international schools and conferences in the area of crystal growth, as well the future membership of this Commission.

In 2007 the IUCr supported three meetings that were very important for the crystal growth community. Commission members were involved in all three.

(1) In May 2007 the Fifth International Conference on Solid State Crystals and the Eighth Polish Conference on Crystal Growth (ICSSC-5 and PCCG-8) were held in the beautiful mountain town of Zakopane, Poland (http://science24.com/event/icssc2007/). There were more than 100 participants. The IUCr was represented by S. Baldochi, K. Kakimoto, A. Moreno and A. Pajaczkowska, all giving invited talks. A short report from the Conference was submitted to the IUCr Newsletter. 
(2) In June 2007 a very successful Workshop entitled Crystallization: Focus on Membrane Proteins was hosted at Brookhaven National Laboratory (http://www.nsls.bnl.gov/newsroom/events/ workshops/2007/crys/). Thanks to the support of the IUCr, young scientists from developing countries had an opportunity to participate in the meeting. Our consultant A. Moreno taught at this venue.

(3) In August 2007 the 13th International Summer School on Crystal Growth, Park City, USA (http://www.crystalgrowth.us/ isscg13/index.php), was held, with P. Rudolph, K. Kakimoto and E. Vlieg as lecturers. The school was attended by 149 participants from 24 countries, more than half being students and postdoctoral fellows; the report from this school is in the American Association for Crystal Growth Newsletter $(2007$, v.2) and will also be in the IUCr Newsletter.

In preparation for the upcoming Osaka Congress this Commission was represented very professionally by its member E. Vlieg (who was also a member of the International Programme Committee). There are four Microsymposia addressing various topics related to crystal growth, chaired by K. Byrappa and S. Feng, H. A. Dabkowska and I. Tanaka, D. Pawlak and V. Orera, and K. Kakimoto and D. F. Bliss. Commission member J. M. Garcia-Ruiz will be a Keynote speaker on the first day of the Congress.

During 2007, the Commission presented its opinion to the Executive Committee about future international meetings (in Mexico and USA).

It is a pleasure to mention that P. Rudolph (consultant to the Commission) presented a short course about the fundamentals of crystal growth in the University of Seoul, Republic of Korea.

As in previous years, many of the Commission members and consultants (S. Baldochi, H. A. Dabkowska, T. Duffar, R. Fornari, K. Kakimoto, A. Moreno, T. Ohachi, P. Rudolph and E. Vlieg) were involved in the work of the International Organization for Crystal Growth.

H. A. Dabkowska, Chair

\subsection{Commission on Crystallographic Computing}

There were three main activities of the Commission during 2007.

(1) The organization of the traditional crystallographic computing school prior to the Osaka Congress. The school will take place in the Kansai Seminar House, Kyoto, Japan, 18-23 August 2008. The school is structured to foster the exchange of ideas via formal lectures, afternoon tutorials, coding challenges and code-comparison sessions. One of the issues to be addressed is the 'retiring crystallographers problem'. A new generation of developers knowledgeable in both crystallography and software development will have to be trained to replace them. Detailed information can be found on the web pages of the school at http://www.iucr.org/comm/ccom/kyoto2008/index.html.

(2) The organization of crystallographic computing sessions at the Osaka Congress. Computing-related sessions are traditionally well attended. Interesting new developments that are addressed include the interesting 'charge flipping' algorithm for $a b$ initio structure determination.

(3) The Commission produces a Newsletter at least once a year, with L. M. D. Cranswick as Editor. Every issue has a special theme for which contributing papers are invited. The November 2007 issue had the theme Crystallographic Computing at Oak Ridge National Laboratory: 1954-1968, with related articles. More details can be found at http://www.iucr.org/comm/ccom/newsletters/index.html.

A. L. Spek, Chair

\subsection{Commission on Crystallographic Nomenclature}

(1) Online Dictionary of Crystallography. The Online Dictionary is now operational. By May 2008 almost 200 substantial definitions will have been entered and grouped into categories. Early work has also been carried out to provide hyperlinks to these definitions from articles published on the Crystallography Journals Online server. The nomination of Editors for the dictionary categories is under way. The next step will be opening the Online Dictionary to the general public, but this requires developing an appropriate filter so that suggestions for new definitions or modifications of existing ones will be checked by the appropriate Editor before they are made definitive. Cooperation is also being established with other community resources such as the wikis being developed by the CCP4 users in the field of biocrystallography. A direct discussion with the developers of the CCP4 will take place in Osaka during the Congress. The Online Dictionary may be consulted at http://reference.iucr.org/dictionary/ Main_Page.

(2) Nomenclature issues. An e-mail debate took place on the nomenclature of ordered structures with split occupancy. However, after lengthy discussions between members, no definitive conclusions were reached and no new definition was introduced.

\section{A. Authier, Chair}

\subsection{Commission on Crystallographic Teaching}

Following the idea of the importance of improving the teaching of the fundamentals of crystallography, during 2007 the Commission was involved in the organization of The Zürich Crystallography School Bring Your Own Crystals, held at the University of Zürich, 5-17 August 2007. G. Chapuis, a member of the Commission, was one of the lecturers and contributed to the finalization of the programme. The School was hosted by the University of Zürich and organized by A. Linden and H.-B. Bürgi. Interested in crystallography, 20 participants, mainly $\mathrm{PhD}$ students from all over Europe, came together to attend this two-week class. Starting with the main principles of diffraction, growing crystals and how to mount them, discussing difficulties and problems and finally solving and refining crystal structures during the practical work, the course covered all topics. The course covered both basic and advanced skills and provided new and more in-depth insights into the subject. Therefore, everyone was able to profit and gain plenty of new knowledge about crystallography. With access to four different types of diffractometers on offer, every student had the chance to set up a crystal measurement on a machine similar to the one their own group was using. Each evening, the class ended with a short summary of the day where students were able to comment on the day's lectures or to mention things they had noticed. The commitment of all of the tutors was extraordinary; there was a total of 90 hours of crystallography. A second School is planned for 2008.

The Commission collaborated in the organization of the International School on Mathematical and Theoretical Crystallography held at the University of Havana, Cuba, 15-20 July 2007, together with the Commission on Mathematical and Theoretical Crystallography and the Commission on Inorganic and Mineral Structures. The programme included: (1) Group Theory Applied to Crystallography: Part I. Dimension-Independent Fundamental Notions of Crystallographic Groups (Lattices, Point Groups, Vector Systems); Classification of Crystallographic Groups (Arithmetic/Geometric Classes, Crystal Systems, Lattice Systems, Crystal Families); (2) Group Theory Applied to Crystallography: Part II. Application of Crystallographic Group Theory to Concrete Problems in Lower-Dimensional Space; 
(3) Twinned Crystals as Polychromatic Objects: Polychromatic Point Groups and their Mathematics; (4) Twinned Crystals as Polychromatic Objects: Reticular and Symmetry Theory of Twins; (5) OD Structures; The Mathematics of Polytypes; and Modeling Modular Inorganic Structures. There were about 40 students, mainly from Cuba and Mexico but also from South America and Europe.

P. Spadon, with K. El Sayed as Co-Chair, was also involved in the organization of MS40 Teaching Crystallography at ECM-24, Marrakech, Morocco, August 2007.

L. M. D. Cranswick edits an online Commission Newsletter that now includes several interesting contributions.

Commission members K. Ogawa, E. Boldyreva and L. M. D. Cranswick were also active members of the International Programme Committee for the Osaka Congress.

\section{P. Spadon, Chair}

\subsection{Commission on Electron Diffraction}

The year 2007 saw the first fruits of a drive by the Commission to increase the number of workshops/schools outside of Europe and the USA. One of these was the 1st IUCr International School of Crystallography in Asia on Electron and X-ray Diffraction, which was held in Taiwan in November 2007. It is hoped that this will continue on a biennial schedule in different Asian countries. A second was the first K. H. Kuo Summer School of Electron Microscopy that was held in Beijing, People's Republic of China, on the topic of Cryo-Electron Microscopy (EM) in Structural Biology, and it is hoped that this will continue on an annual basis rotating between biological EM and EM of hard materials. A third was Electron Microscopy and Multiscale Modeling 2007 (EMMM 2007), which was held in Moscow, Russia, $3-$ 7 September 2007. The EMMM 2007 Conference brought together leading experts in electron microscopy and materials modelling from around the world to explore how to synergistically combine atomic scale characterization and modelling to enhance the development of new materials. Preliminary discussions are taking place to hold the second of these conferences in 2009.

The Commission has also been involved in a number of related activities; for instance, in helping to organize a reasonably large number of sessions involving electron microscopy at the Osaka Congress (more than in several of the prior Congresses), as well as a satellite meeting to be held after the meeting in Nagoya.

The Commission's home page is maintained by L. D. Marks, and can be found at http://www.numis.northwestern.edu/IUCR_CED.

\section{D. Marks, Chair}

\subsection{Commission on High Pressure}

Combining high pressure with crystallography remains a very challenging and growing field with a large variety of technical developments and scientific applications. The task of the Commission is to provide platforms that help the dissemination and exchange of new techniques, ideas and scientific achievements in this field. The main tools to achieve this goal are special workshops in each of the two years between the triennial IUCr Congresses. In Congress years the Commission tries to integrate this workshop into the Congress by organizing Microsymposia specifically targeted on high-pressure crystallography.

The 2007 workshop was held at Wadham College, Oxford, UK, 3-7 September. Commission Secretary J. S. Loveday acted as the local organizer. This workshop was again a great success. Eighty-five participants gathered in a historic music pavilion to follow 11 oral sessions and poster presentations. The workshop finished with a tour through the new synchrotron facility (Diamond) and the highly successful ISIS neutron spallation source at Rutherford Appleton Laboratory.

This workshop enabled us to hold a closed Commission meeting. Seven Commission members were present [M. Kunz (Chair), J. Tse (Treasurer), J. S. Loveday (Secretary), S. A. T. Redfern, S. Tolbert, R. Winter and R. J. Nelmes (Consultant)]. The following topics were discussed:

IUCr 2008. N. Hamaya represents the Commission on the International Programme Committee. Two of our three proposed Keynote Lecturers and six Microsymposia were approved:

Keynote Lecturers: G Galli (USA): Chair: A. Oganov (Switzerland): Computational Crystallography at High Pressure; I. Goncharenko (France): Chair: O. Shimomura (Japan): Advances in HighPressure Neutron Diffraction.

Microsymposia: six proposed, six approved - two held jointly with other Commissions, as follows:

Biological and Soft Condensed Matter under Pressure: Chair: F. Fabbiani (UK), Co-Chair: R. Winter (Germany). Jointly with the Commission on Structural Chemistry.

Computational Crystallography at Extreme Conditions: Chair: R. Ahuja (Sweden), Co-Chair: J. Tse (Canada).

High Pressure Studies on Advanced and Nano-Materials: Chair: N. Dubrinovskaia (Germany), Co-Chair: V. Solozhenko (France).

Phase Transitions and Physical Properties at High Pressure: Chair: R. Benedetti (USA), Co-Chair: G. Shen (USA).

Liquids and Amorphous Systems at High Pressure: Chair: M. Guthrie (UK), Co-Chair: Y. Katayama (Japan).

Crystallography of Planetary Materials at Extreme Conditions: Chair: T. Yagi (Japan), Co-Chair: J.-B. Parise (USA). Jointly with the Commission on Inorganic and Mineral Structures.

Commission members. For the next triennium, a number of Commission members will be retiring (including the Secretary, Treasurer and Chair). Some of the departures can be replaced by current consultants, who in turn should be replaced. The Commission is collecting proposals for replacements while keeping in mind that all current sub-fields of high-pressure crystallography should be represented (for example, neutrons, synchrotrons, material science, biology and soft matter etc.). In view of the upcoming workshop in the People's Republic of China in 2009, it would also be sensible to have a Chinese representative on the Commission. H. Liu, formerly at APS now in Beijing, has offered to help with local contacts for the 2009 workshop.

Web page. The current web page is in a dire state. This is relevant since for many outsiders the Commission's web page is potentially their first view into our field. In order to ensure continuing updates, it is suggested that an institution should take responsibility for the web page and delegate the work to a postdoc. If this postdoc moves on, the job should be passed on to her/his successor. The Edinburgh Centre for Science at Extreme Conditions volunteered to assign a postdoc to this job. At the moment this will be I. Loa.

The workshop in 2009 will be held in Harbin (Heilongjiang Province, N. E. China). The Commission hopes that this workshop will be a starting point to intensify scientific exchange with the Chinese high-pressure crystallography community.

In 2009, Commission consultant P. Dera is organizing a summer school on high-pressure crystallography in Erice, Italy. The school is scheduled to take place 4-14 June 2009. This is a follow-up to the very successful summer school organized in 2003.

\section{Kunz, Chair}




\subsection{Commission on Inorganic and Mineral Structures}

Contacts among the members and consultants of the Commission (CIMS) have been maintained mainly via e-mail and the web site at http://www.crystallography.fr/cims/ administered by consultant member M. Nespolo. Some members had the opportunity of meeting and discussing CIMS activity on the occasion of ECM-24 (Marrakech, Morocco, 20-27 August 2007).

CIMS has supported applications for financial support from the IUCr for the following meetings that have been organized during 2007; the active participation of members of CIMS is given for each meeting.

(1) XVI International Conference on Crystal Chemistry and Diffraction Studies of Minerals, Miass, Russia, 2-6 July 2007 (http:// meetings.mineralogy.ru/Default.asp). W. Depmeier, G. Ferraris and D. Yu. Pushcharovsky were members of the Programme Committee; W. Depmeier and G. Ferraris were also invited speakers.

(2) Workshop on Minerals as Advanced Materials, Apatity, Russia, 8-12 July 2007. W. Depmeier and G. Ferraris were invited speakers. An outcome of this workshop is the volume Minerals as Advanced Materials I (edited by S. V. Krivovichev) published by Springer.

(3) International School on Mathematical and Theoretical Crystallography, Havana, Cuba, 15-20 July 2007 (http://www. crystallography.fr/mathcryst/havana2007.htm). G. Ferraris and M. Nespolo were organizers and speakers. The texts of the lectures are available at the site shown above.

(4) ACA Annual Meeting, Salt Lake City, USA, 21-26 July 2007.

(5) 41st IUPAC World Chemistry Congress, Torino, Italy, 5-11 August 2007 (http://www.iupac2007.org/) to run the section 4a-4 Structural Aspects of Crystalline Materials (from inorganic to macromolecular); G. Ferraris was a proponent.

(6) ECM-24, Marrakech, Morocco, 22-27 August 2007, and its satellite The Enchanting Crystallography of Moroccan Ornaments, 20-22 August 2007. The satellite (http://www.crystallography.fr/ mathcryst/marrakech2007.htm) was organized by the Commission on Mathematical and Theoretical Crystallography chaired by $M$. Nespolo, consultant member of CIMS. At ECM-24 P. Thomas and W. Depmeier were members of the Programme Committee; J. Rocha was a Keynote speaker; G. Ferraris and P. Thomas were Chairs of Microsymposia.

(7) II International Conference on Crystallogenesis and Mineralogy, St Petersburg, Russia, 1-5 October 2007 (http://www.minsoc.ru/ confs.php?cid=39) and its satellite Structural Chemistry of Inorganic Actinide and Lanthanide Compounds, St Petersburg, Russia, 29 September - 1 October 2007). W. Depmeier was Chair and invited speaker at both meetings. G. Ferraris and D. Yu. Pushcharovsky were members of the International Programme Committee.

(8) Workshop on Structure Elucidation by Combining Magnetic Resonance, Computation, Modelling and Diffraction (SMARTER), Aveiro, Portugal, 6-7 September 2007, organized by J. Rocha on behalf of CIMS; G. Ferraris was a member of the International Programme Committee. The aim of SMARTER was to bring together specialists from the different areas of materials science, such as materials chemists and processing engineers, diffraction and spectroscopy scientists, and computational structuralists, that may contribute to the development of a common language for a SMARTER approach to structure solving, using geometrical, diffraction, modelling and NMR crystallographic methods. SMARTER was attended by some 110 researchers, PhD students and postdocs from France, Germany, India, Italy, Poland, Portugal, Spain, UK and USA. The scientific programme consisted of 20 (mostly) thirty-minute talks and 12 posters. In a lively discussion at the end, the attendees found the SMARTER workshop concept very interesting and timely, and agreed that it would be useful to continue it and to hold it again in Aveiro in 2009.

(9) MSA-GS-ANL short course on 'Amphiboles', Rome, Italy, 2931 October 2007 (http://www_crystal.unipv.it/amphiboles/home.htm). F. C. Hawthorne, consultant member of CIMS, was an organizer and speaker. An outcome of this short course has been the volume Amphiboles: Crystal Chemistry, Occurrence, and Health Issues (edited by F. C. Hawthorne, R. Oberti, G. Della Ventura and A. Mottana), No. 67 of the series Reviews in Mineralogy and Geochemistry.

(10) CIMS contributed to suggest topics and authors for the Special Issue 60 years of Acta Crystallographica and the IUCr; D. Pandey co-authored (with A. K. Singh and S. Baik) the article Stability of Ferroic Phases in the Highly Piezoelectric $\mathrm{Pb}\left(\mathrm{Zr}_{x} \mathrm{Ti}_{1-x}\right) \mathrm{O}_{3}$ Ceramics.

During 2007 CIMS has been active in the organization of the following meetings to be held in 2008 .

II International Workshop on Layered Materials 'Structure and Properties'. Vercelli, Italy, 28-29 March 2008 (http://www. layeredmaterials.mfn.unipmn.it/). G. Ferraris is member of the Organizing Committee. W. Depmeier, G. Ferraris and D. Pandey are members of the Programme Committee. J. Rocha is an invited speaker. As with SMARTER in 2007, this workshop intends to attract researchers, like materials scientists, who, in spite of their high-level crystallographic production, are not regular attendees of $\mathrm{IUCr}$ general meetings.

P. Thomas represented CIMS on the International Programme Committee of the Osaka Congress; taking into account suggestions from CIMS members, she was able to include the following events of specific interest for our Commission (some are shared with other IUCr Commissions): (1) MS70 Crystal Chemistry and Crystallography of Aperiodic Crystals; (2) MS77 Diffuse Scattering in Partially Ordered/Disordered Systems; (3) MS93 Crystallography of Planetary Materials at Extreme Conditions; (4) MS94 From Minerals to Materials; (5) MS95 Multi-Technique Approach to the Determination of Inorganic Structures; (6) MS97 Perovskites and Related Materials; (7) MS98 Structure-Properties Correlations and Phase Transition in Inorganics; (8) KN11 Crystallochemical Basis of Synthetic Mineral Immobilizations, speaker T. White; (9) KN36 Structure Refinement and Structure Modelling: a Chemical Probe for Complex Mineral Groups, speaker R. Oberti; (10) KN23 Structural Phase Transitions, speaker J. M. Perez-Mato; (11) G. Ferraris, M. Nespolo and D. Pandey will be Chairs of Microsymposia or Keynote sessions.

Besides the activity given above, members of CIMS have reported to the Chair the following personal activity related to the purposes of the Commission.

W. Depmeier: Keynote Lecture at the Jahrestagung 'Deutsche Gesellschaft für Kristallographie', Bremen, Germany, 5-9 March 2007; invited speaker at Workshop on Time- and TemperatureResolved X-ray Powder Diffractometry: New Developments in Techniques and Applications, Fraunhofer ICT, Berghausen, Germany, 8-9 November 2007; Chair of SIG 5 Mineralogical Crystallography of the European Crystallographic Association.

M. Matsui: Editor of Physics and Chemistry of Minerals.

L. B. McCusker: Invited lectures: (1) Canadian Society for Chemistry Meeting, Winnipeg, Canada: Deciphering the Structural Information in a Zeolite Powder Diffraction Pattern; (2) Berzelii Centre EXSELENT on Porous Materials, University of Stockholm, Sweden: Zeolite Structures and their Determination from Powder Diffraction Data; (3) Rayons X et Matière, RX2007, Dijon, France: 
Combining Techniques to Solve Complex Zeolite Structures. Coauthor (with C. Baerlocher and D. H. Olson) of the sixth revised edition of Atlas of Zeolite Framework Types (Elsevier). Member of the Programme Committee for IZC-15, Beijing, People's Republic of China. Co-editor of Acta Crystallographica Section B. Maintenance of the International Zeolite Association web sites http://www.izaonline.org/ and http://www.iza-structure.org/; redesign (together with C. Baerlocher) of the web Database of Zeolite Structures (http:// www.iza-structure.org/databases/).

M. Nespolo: Associate Editor of European Journal of Mineralogy; Secretary of the Special Interest Group SIG5 on Mineralogical Crystallography of the ECA.

D. Pandey: Microsymposium Chair for Functional Materials at the International Conference on Advanced Materials (sponsored by IUMRS) held in Bangalore, India, in 2007.

D. Yu. Pushcharovsky: Associate Editor of European Journal of Mineralogy.

J. Rocha: Member of the Editorial Board of European Journal of Inorganic Chemistry.

E. Tillmanns: Chief Editor of European Journal of Mineralogy; Chair of the Organizing Committee of the 20th General Meeting of the International Mineralogical Association (IMA) (Budapest, Hungary, 2010).

\section{G. Ferraris, Chair}

\subsection{Commission on Mathematical and Theoretical Crystallography}

The Commission (MaThCryst) organized the following activities in 2007:

(1) A School at the University of Havana, Cuba, 15-20 July 2007, organized through Commission consultant E. E. Rams and in cooperation with the Commission on Crystallographic Teaching and the Commission on Inorganic and Mineral Structures. The School was held on five days and spanned topics from basic group theory to higher-dimensional crystallography, polychromatic symmetry, OD structures, polytypes and modular structures. The School, in addition to the lecturers, was attended by 38 participants from 11 countries (Austria, Cuba, Ecuador, Guatemala, Israel, Mexico, Poland, Peru, South Africa, Switzerland, Venezuela), and represented for many of the participants a rare occasion to obtain a solid introduction to crystallography. Didactic material from the satellite is available from the satellite meeting web site (http://www.crystallography.fr/ mathcryst/havana2007.htm).

(2) A satellite meeting of ECM-24, Marrakech, Morocco, 20-22 August 2007, devoted to The Enchanting Crystallography of Moroccan Ornaments. The satellite, attended by 28 participants from 11 countries (Denmark, France, Germany, Italy, Japan, Morocco, Spain, Sweden, South Africa, Switzerland, USA), under the scientific direction of E. Makovicky (University of Copenhagen, Denmark), consisted of lectures on the symmetry of Moroccan ornaments and practical demonstrations during which the participants could realize some typical patterns under the guidance of J.-M. Castera (Zellij multipuzzles and muqarnas) and of a local craftsman who showed how Moroccan ornaments are produced. The satellite ended with an excursion to the Kasbah of Telouet, a site renowned for the richness of its ornaments. A picture taken from this site is used as the cover of Acta Crystallographica Section A, Volume 64 (2008). Didactic material from the satellite is available from the satellite meeting web site (http://www.crystallography.fr/mathcryst/marrakech2007.htm).

MaThCryst contributed to suggest topics and authors for the Special Issue 60 years of Acta Crystallographica and the IUCr, which contains the article Does Mathematical Crystallography still have a Role in the XXI Century?, written by M. Nespolo.

Forthcoming activities include a summer school at Gargnano, Lake Garda, Italy, 27 April - 3 May 2008 (see http://www.lcm3b.uhpnancy.fr/mathcryst/gargnano2008.htm), in cooperation with the Commission on Crystallographic Teaching.

The following activities fall within the framework of the Osaka Congress:

KN29 Keynote Lecture on Crystal Design and Synthesis: Reticular Chemistry by O. M. Yaghi; Chair D. Proserpio.

MS89 Microsymposium in honour of E. Ascher and J. J. Burckhardt; Chairs H. Grimmer and M. Nespolo, invited speakers: A. Janner (The Netherlands), M. Senechal (USA).

Evening Session on Art and Crystallography; Chair M. Nespolo. There will be a satellite conference of ECM-25 on Symmetry and Crystallography in Turkish Art and Culture, Istanbul, Turkey, 7-9 August 2009 (see http://www.crystallography.fr/mathcryst/ istanbul2009.htm).

M. Nespolo, Chair

\subsection{Commission on Neutron Scattering}

In 2007, the 4th European Conference on Neutron Scattering (ECNS), an important gathering of the neutron research community with around 700 participants from Europe and the rest of the world, was held in Lund, Sweden, 25-29 June. The ECNS is held every four years and serves as a multidisciplinary meeting for users of neutron techniques from a wide range of disciplines (such as physics, chemistry, biology, material sciences and earth sciences) as well as scientists working on the development of neutron instruments and facilities.

At ECNS 2007 two prizes were awarded during a special ceremony: the Walter Hälg Prize and the Erwin Felix Lewy Bertaut Prize. Every two years, the European Neutron Scattering Association (ENSA) awards the Walter Hälg Prize to European scientists for outstanding work in neutron scattering with a long-term impact on scientific and/or technical neutron-scattering applications. The Walter Hälg Prize for 2007 was awarded to J. Penfold (Rutherford Appleton Laboratory, UK) in recognition of his ground-breaking work on neutron reflection - a method that he developed into an invaluable tool in colloid and interface science.

The Erwin Felix Lewy Bertaut Prize is awarded by the European Crystallographic Association (ECA) and the European Neutron Scattering Association (ENSA) to young European scientists in recognition of notable experimental, theoretical or methodological contributions in the field of the investigation of matter using crystallographic or neutron-scattering methods. In 2007, the Prize Committee decided to award the Erwin Felix Lewy Bertaut Prize to H. M. Rønnow (Ecole Polytechnique Fédérale de Lausanne, Switzerland), whose work is focused on experimental and theoretical aspects of quantum magnetism. He has also been involved in the development of neutron instrumentation as well as simulation and data-analysis software.

Besides ECNS, several conferences relevant to neutron scattering were held in 2007 all over the world; for example the 18th meeting of the International Collaboration on Advanced Neutron Sources (ICANS-XVIII), Dongguan, southern China, 25-29 April. Furthermore, numerous neutron courses and schools were arranged for young scientists. These included (1) the 28th HMI School on Neutron Scattering, Berlin, Germany, 26 February - 2 March; (2) the 6th PSI Summer School on Condensed Matter Research, Zuoz, Switzerland, 18-25 April; (3) the 11th JCNS Laboratory Course - Neutron Scat- 
tering, Jülich/Garching, Germany, 3-14 September; (4) the 10th Oxford School on Neutron Scattering, Oxford, UK, 4-14 September; and (5) the 4th Central European Training School on Neutron Scattering (CETS2007), Budapest, Hungary, 23-28 April.

One important topic concerning neutron sources worldwide is the discussion about the European Spallation Source (ESS). In 2007, three governments (the Spanish, Swedish and Hungarian) put forward official bids for the investment costs in order to host the ESS but so far the final location of the world's most powerful spallation source remains to be decided.

In 2007, the existing neutron sources showed successful operations. Changes/upgrades that have been made through the year and news about the sources are summarized below.

The continuous spallation source SINQ at the Paul Scherrer Institut (PSI) in Switzerland was back in operation in April 2007, as scheduled, after the annual shutdown at the end of 2006. In December 2006, the MEGAPIE (Megawatt Pilot Experiment) target test was successfully completed after four months of operation. The MEGAPIE project is an international endeavour, with the aim to design, build, operate and explore a liquid-metal spallation target on the basis of a lead-bismuth eutectic for a beam power approaching $1 \mathrm{MW}$. The main goal of the initiative is to increase the neutron flux at SINQ and to demonstrate the feasibility of safely running a liquid heavy-metal target.

At the pulsed spallation source ISIS, Rutherford Appleton Laboratory, Oxfordshire, UK, the Second Target Station Project achieved a major milestone. On 14 December, the first proton beam was successfully delivered to the new target station. The Second Target Station Project will double the capacity of the ISIS Research Centre and significantly increase its capability for nanoscience applications. It will open for experiments in autumn 2008 and is expected to operate for at least 20 years.

One year after commissioning, the Spallation Neutron Source (SNS) at the Oak Ridge National Laboratory (ORNL) has established a record as the world's most powerful pulsed neutron spallation source. The SNS's neutron beam reached $183 \mathrm{~kW}$ on 11 August, surpassing the $163 \mathrm{~kW}$ record held by the ISIS facility at Rutherford Appleton Laboratory. In addition to SNS, ORNL operates a second neutron source: the High Flux Isotope Reactor (HFIR). At the 40year-old HFIR a new cold source and new instruments were brought into operation in 2007.

The ILL (Institut Laue-Langevin, Grenoble, France), the most intense reactor neutron source in the world, celebrated its 40th anniversary and launched the second phase of the so-called Millennium Programme. The overall goal of the Millennium Programme, which started in 2000, is to modernize the infrastructure and instrument suite to provide the best possible experimental facilities and support to its European users over the next two decades. In this second period (2007-2013) five new instruments will be built and four others will be upgraded.

At FRM II, the high-flux reactor source in Munich, Germany, a new neutron guide hall was inaugurated in May. This hall includes cold and thermal neutron guides and a positron beam. At a later stage, ultra cold neutrons will be guided to the hall as well. The first neutrons in the new guide hall are expected by the end of 2009. FRM II was set in operation in 2004 and reached its nominal power of $20 \mathrm{MW}$ in 2006 when the first neutrons were delivered to users.

After 49 years of successful operation, Australia's first nuclear reactor HIFAR (High Flux Australian Reactor) was permanently shut down on 30 January. The 10 MW High Flux Australian Reactor was used for materials research, to produce radioactive materials for medicine and industry, and to irradiate silicon for the high- performance computer industry. HIFAR has been replaced by a new research reactor, known as OPAL (Open Pool Australian Lightwater reactor). This $20 \mathrm{MW}$ pool-type research reactor was officially opened in April 2007 at the Australian Nuclear Science and Technology Organization (ANSTO) Research Establishment in south Sydney, Australia. Unlike HIFAR, OPAL has a cold neutron source to enable research on biological materials.

In the People's Republic of China, the construction of a new research neutron reactor is making good progress. The China Advanced Research Reactor (CARR), a $60 \mathrm{MW}$ facility, is expected to become critical in 2008. In 2007 the first meeting of the International Advisory Committee of CARR took place in Beijing.

We have seen 2007 to be a successful year in the world of neutron scattering -2008 promises to be just as exciting.

\section{Steiner, Chair}

\subsection{Commission on Powder Diffraction}

No report has been received from the Chair.

W. I. F. David, Chair

\subsection{Commission on Small-Angle Scattering}

4.16.1. Commission meetings and communication. Communications between Commission members were by performed by e-mail or during personal meetings at national and international conferences. In particular, discussions of the work of the Commission were held at the Annual Meeting of the American Crystallographic Association (Salt Lake City, USA, July 2007) and at the Biology and Synchrotron Radiation Conference (Manchester, UK, August 2007), where most of the Commission members were present.

4.16.2. Activities. The Commission has been actively preparing for the Osaka Congress. After several rounds of discussions, nominations were made for the topic of the Keynote Lecture in SAS (Advances in Micro- and Nano-SAXS). The Commission felt that it would be very timely to present broadly at the Congress the tremendous progress achieved in SAXS by using high-brilliance synchrotron radiation, its applications in bio- and nanotechnology and in medicine, and the future perspectives for the technique. This lecture will be given by Commission member P. Fratzl. Moreover, topics for four Microsymposia were suggested and approved. These Microsymposia will be Co-Chaired by the following Commission members:

(1) Complementarity of SAXS and SANS with other Structural Methods in Molecular Biology; Co-Chaired by J. Trewhella.

(2) Micro-SAXS for Nanoscience and Medicine; Co-Chaired by P. Fratzl.

(3) Time-Resolved and Coherent X-ray Scattering and Imaging; Co-Chaired by P. Thiyagarajan.

(4) Advances in Grazing Incidence, Reflectivity and Diffuse Scattering; Co-Chaired by A. Allen.

Given the necessity of the rotation of the membership of the Commission, we have thoroughly discussed the future composition of the Commission through e-mail exchange, with an objective to maintain national and gender balance.

Taking into account past experience, it was decided to approach the International Advisory Committee of the next triennial SAS conference in Oxford, UK (2009), and ask them to work together with the Commission in soliciting applications for the venue of the next SAS conference in 2012. It is envisaged that the two bodies vet suggestions regarding the selection of the venue by reviewing the available bids before and/or during SAS 2009 and come up with a 
balanced recommendation for the SAS 2012 venue (to be approved by the SAS 2009 attendees). Such a selection scheme will also be proposed for future SAS conferences. G. Kostorz agreed to be the liaison person from the Commission in establishing the new procedure.

4.16.3. Educational activities. The members of the Commission were actively involved in presenting seminars and tutorial lectures at various schools and workshops worldwide explaining SAS methods to young students and researchers from different fields.

In particular, D. Svergun and J. S. Pedersen presented lectures at the 1st Australian Workshop on Solution Scattering from Biological Macromolecules, University of Melbourne, Australia, 23-24 July 2007, organized by T. Mulhern, and at the Practical Course on SmallAngle Scattering on Biological Molecules, Copenhagen, Denmark, 25-30 November 2007, organized by L. Arleth and B. Vestergaard. D. Svergun conducted tutorials on data analysis at these courses.

D. Svergun presented tutorial lectures on biological SAS at the British Crystallographic Association Meeting, Kent, UK, 17-19 April 2007, and at the Danish Physical Society (DFS) Meeting, Nyborg, Denmark, 19-20 June 2007. His group wrote a Wikipedia entry on biological small-angle X-ray scattering (http://en.wikipedia.org/wiki/ Biological_small-angle_X-ray_scattering).

J. S. Pedersen lectured at the 3rd International Workshop on SmallAngle X-ray Scattering, Materials Center Leoben, Austria, 10-11 September 2007, and he also gave a lecture with the title Future Prospects of Small-Angle X-ray Scattering at the workshop held in connection with the planned MAX VI synchrotron in Lund, Sweden.

P. Thiyagarajan gave lectures on the Principles of Small-Angle $\mathrm{X}$-ray and Neutron Scattering and their Applications in Nanomaterials Characterization at the Annual Argonne Neutron and X-ray School, Argonne, USA, 20 August 2007, at the International Symposium on Metastable and Nanostructured Materials, ISMANAM 2007, Corfu, Greece, 25-31 August 2007, and at the Annual SSRL Summer School, Stanford, USA, 10 September 2007 on SAXS Applications in Biology. He also conducted a practical on TOF-SANS applications for the study of the phase behaviour of block copolymers.

A. Allen was involved in encouraging the preparation of various new SAS guides at NIST (Gaithersburg, USA) for SANS and at APS (Argonne, USA) for SAXS and especially USAXS. The SANS guide written by B. Hammouda was finally released in February 2008 (660 pages) and presents a great deal of tutorial information for SANS; this guide may be obtained from http://www.ncnr.nist.gov/staff/ hammouda/the_SANS_toolbox.pdf. A. Allen also gave tutorial talks at the European Ceramic Society Conference, Berlin, Germany, 20 June 2007, and at the American Crystallographic Association Annual Meeting, Salt Lake City, USA, 21-26 July 2007.

J. Trewhella continued to promote educational activities, especially around the Pacific Rim. She gave review and tutorial lectures at: the Crystal 25 Meeting of the Society of Crystallographers in Australia and New Zealand, Hunter Valley, NSW, 10-13 April 2007; Neutrons in Biology, Satellite Meeting of the European Biophysics Congress, Oxfordshire, UK, 11-13 July 2007; American Crystallographic Association Annual Meeting, Salt Lake City, USA, 21-26 July 2007; Pittsburg Diffraction Conference, Buffalo, USA, 26 September 2007; and at the Asian Crystallographic Association Meeting, AsCA '07, Taiwan, 4-7 November 2007.

N. Yagi talked on the use of X-ray detectors for SAXS at the SPring-8 Summer School, Himeji, Japan, 6-9 July 2007, which was oriented towards potential Japanese users of synchrotron radiation. He also gave a practical course on SAXS at the Cheiron Summer School, SPring-8, Himeji, Japan, 18-19 September 2007. The School was organized by the Asia-Oceania Forum for Synchrotron Radiation Research for young people who hope to work at synchrotron facilities in the future. About 40 people from abroad (Asia and Australia) and about 20 from Japan came to this Summer School, which will be held again in 2008 at SPring-8.

4.16.4. Community-building activities. The members of the Commission continued to contribute to the widening of the community of SAS users in their laboratories and large-scale facilities. They also took part in conferences, workshops and meetings devoted to the future development of SAS and especially in the joint use of SAS with other structural techniques.

J. S. Pedersen continued to support new users at his laboratory's SAXS facility at the University of Aarhus, Denmark, which is becoming increasingly popular among the universities and research institutes in Denmark, Scandinavia and the rest of Europe. He also continued to train students and postdocs in the SAS technique in Aarhus.

D. Svergun gave a talk on the possibilities of biological SAXS at a Workshop at the Canadian Light Source (CLS) in Saskatoon, Canada, 5-6 November 2007, where future construction of beamlines at this synchrotron was discussed. The beamline X33 at EMBL Hamburg continued to display the $20-30 \%$ increase of users (from 27 countries worldwide) in 2007. The first liquid-handling robot for solution SAXS experiments and the novel PILATUS pixel X-ray detector were made available for users. A web SAS forum was created at http://www.saxier.org/forum, which now has about 100 registered participants.

P. Thiyagarajan continued to run a highly productive user programme at the Intense Pulsed Neutron Source (IPNS) where annually over 20 groups use the TOF-SANS instrument. He trained several graduate students in the SANS and reflectivity experiments at IPNS and SAXS at APS, and continued to provide SAS-relevant analysis software packages to the users of IPNS and APS. To expand the user base and to inform the scientific community he presented a plenary talk on the Advanced Photon Source Capabilities for the Study of Soft and Biomolecular Materials (Plenary Talk), DOE-BES Biomolecular Materials Contractors' Meeting, Warrenton, USA, 4-7 November 2007.

In an effort to help the SAXS users from Brazil and other LatinAmerican countries, I. Torriani established an interface with the researchers at the Brazilian synchrotron in Campinas on an individual basis to allow more efficient data collection and data treatment. This seems to be giving better results than short training courses.

J. Trewhella has been appointed to the Neutron Decadal Planning Group to draft the plan for neutron scattering in Australia for the next decade.

In a move to establish standards for publication and deposition of SAS data, J. Trewhella and D. Svergun together with J. M. Guss (Commission on Journals) and E. N. Baker (Commission on Journals and Protein Data Bank) decided to organize a meeting to be scheduled at the Osaka Congress. This meeting should initiate a process of working out community-endorsed standards. H. M. Berman of the Protein Data Bank has also been informed of the effort and has expressed strong interest.

4.16.5. Consultant activities. D. Svergun and J. S. Pedersen served as members of the Scientific Committee at Geesthacht Neutron Scattering Facility (GeNF) at GKSS Research Centre, Geesthacht, Germany. J. S. Pedersen was a panel member for the review of the CRG beamline BM26 (6-7 November 2007) at the European Synchrotron Radiation Facility (ESRF, Grenoble, France). D. Svergun was a member of the proposal review Committee on Soft Condensed Matter of the ESRF. 
P. Thiyagarajan continues to serve as a member of the Advisory Committee for the BioCAT facility at the APS, a reviewer for the 12ID SAXS facility upgrade proposal (APS, Argonne, USA), and a regular reviewer of the beam-time proposals for NIST (Gaithersburg, USA) and SSRL (Stanford, USA).

J. Trewhella continued to work as Chair of the Programme Advisory Committee (for beam-time allocations) at the Bragg Institute, ANSTO, Australia.

G. Kostorz and A. Allen served as Guest Editors for the SAS 2006 Special Issue of Journal of Applied Crystallography, to be published in 2008 .

4.16.6. Organizational activities. P. Thiyagarajan is the 2007 SASSIG Chair Elect of the American Crystallographic Association (ACA) to organize and coordinate the SAS-related sessions at the 2008 Annual Meeting of the ACA, Knoxville, USA. At the 2007 Annual Meeting of the ACA, Salt Lake City, USA, he organized a planning session and secured a number of slots and themes for the SAS sessions at the ACA 2008 meeting. He also will Co-Chair the Time-Resolved Scattering session at this meeting.

In October 2007, A. Allen's home institute, NIST (Gaithersburg, USA) hosted the canSAS V workshop. Progress was made in several areas including development of standardized portable $1 \mathrm{D}$ data formats (both IUCr sasCIF and SAS NeXus), priorities for developing candidate standards for SAXS and SANS, as well as more general standardization issues. Agreed protocols for moving between data formats were seen as a critical need for the future, as was the development of wavelength and intensity standards.

J. Trewhella served as a member of the International Advisory Committee for the Neutrons in Biology Meeting, Rutherford Appleton Laboratories, UK, July 2007. She was the Programme Chair for the 2007 Annual Meeting of the ACA, Salt Lake City, 21-26 July 2007. Small-angle scattering featured prominently with five well attended sessions focusing on techniques and applications.

D. Svergun applied for EMBO funds to organize an EMBO Practical Course on Solution Scattering from Biological Macromolecules in Hamburg, Germany. The proposal was accepted and the course will take place in October 2008, at EMBL Hamburg.

I. Torriani served as a member of the International Programme Committee of the Osaka Congress, taking part in the organization of the general programme and advising on the SAXS sessions.

N. Yagi is an organizer of the satellite meeting of the Osaka Congress: X-ray and Neutron Techniques for Nano-Structural Research, to be held at SPring-8, 21-23 August 2008.

J. S. Pedersen is a member of the Organizing Committee of the European Summer School entitled Scattering Applied to Soft Condensed Matter, Bombannes, Gironde, France, June 2008.

4.16.7. Technical activities. P. Thiyagarajan and A. Allen continued to be active in the advisory role for the developments of new capabilities for SAXS, USAXS, GISAXS, ASAXS and area detector development at 12-ID (Argonne National Laboratory, USA).

The group of D. Svergun released the new version 2.2 of the program suite $A T S A S$ for the analysis of small-angle scattering data. Since 2003 , this package, which is freely available for academic users, was downloaded more than 15000 times from the EMBL web site by visitors from more than 500 laboratories worldwide. New methods for automated data processing and for the analysis of flexible systems were added and the programs can be run online via the web.

In 2007, A. Allen participated in the work at NIST (Gaithersburg, USA) to develop three nanoparticle reference materials (RMs): NIST RMs 8011, 8012 and 8013, respectively, for nominal 10, 30 and $60 \mathrm{~nm}$ gold nanoparticles in aqueous suspension, for use in biological research applications. NIST RMs are one step down from Standard RMs in terms of NIST traceability, but a full uncertainty analysis is still undertaken for the reference value (mean particle diameter in each case). Informational values, reported for some techniques, included the dispersion width in terms of diameter, concentration, surface area and shape. Many measurement techniques were used including both SAXS (modified Rigaku laboratory instrument at NIST) and the NIST-built USAXS instrument at APS (Argonne, USA). Details of the combined SAXS and USAXS measurements are included in the certificates (issued with the available stockpile in January 2008). He has also continued his service on the Beam-Time Allocation Committee for SANS at the Neutron Center for Neutron Research as the only 'NIST-but-non-NCNR' staff member.

During 2007, D. Svergun worked together with I. D. Brown (IUCr Committee for the Maintenance of the CIF Standard) to finalize and ultimately approve the sasCIF format. The work is largely finished and the standard is expected to be approved soon.

I. Torriani continued to coordinate the SAXS facilities at the LNLS (Brazil). The relocation of the SAXS1 beamline to a new bending magnet port was completed, with improved layout and redesigned optics to allow installation of a rheometer and other polymer in situ experiments. She coordinated commissioning of new instrumentation at the new SAXS2 beamline, which involved multiple-sample chambers and optimization of data acquisition.

D. I. Svergun, Chair

\subsection{Commission on Structural Chemistry}

During 2007 the Commission has promoted the activity of the structural chemistry crystallography community by recommending and supporting meetings addressing scientific themes of particular interest for structural chemistry. Several meetings of this type have been held in 2007, including the School on Materials Applications of the Organic Solid State (SMAOSS) and the XVIII International Conference on the Chemistry of the Organic Solid State (XVIIIICCOSS), Merida, Venezuela, 1-6 and 8-13 July 2007, and the American Crystallographic Society Annual Meeting (Salt Lake City, USA, 21-26 July 2007).

The next American Crystallographic Association Annual Meeting, Knoxville, USA, 31 May - 5 June 2008, will be supported by the Commission, with particular attention to encouraging participation of young researchers from Central and South American countries.

Commission members have also contributed to the planning and organization of Microsymposia covering the most emergent topics in structural chemistry within national and international congresses, workshops and schools during 2007.

The Commission has worked to increase the number of researchers registered in the World Directory of Crystallographers, by collecting and filtering lists of participants at events related to crystallography.

A key activity of the Commission during 2007 was contributing to the planning of the Osaka Congress. The Commission Chair, A. Bacchi, and A. Nangia were designated by the Commission to represent it on the International Programme Committee to contribute to the suggestions and planning of topics for Plenary Lectures, Keynote Lectures, Microsymposia and Chairs for the Congress. Structural chemistry will be present in Osaka at all levels: plenary talks, invited presentations, topical sessions and posters, showing the vitality of the discipline and the growing interest of the crystallographic community towards topics related to structural chemistry. Joint Microsymposia with other Commissions on common topics have 
also been encouraged as a way of highlighting the interdisciplinarity of structural chemistry.

\section{A. Bacchi, Chair}

\subsection{Commission on Synchrotron Radiation}

The aim of the Commission is to promote access and awareness of crystallographers worldwide to the world's synchrotron-radiation (SR) facilities. A special focus has continued on instrumentation and methods - in particular, detectors. An increasingly important issue to address concerns possible synergies between classical storage rings and future free-electron-laser- (FEL-) based sources. Two main activities for the Commission in 2007 have been support for various conferences, listed below, and help in organizing the Osaka Congress.

The Commission has endorsed the following meetings and activities, and/or has been involved via its members:

(1) The 2007 meeting of the Asian/Oceanic Forum (AOF) for Synchrotron Radiation Research.

(2) The 2007 RapiData course on automated data collection; in particular, it supported the participation of scientists from South and Central America.

(3) The Commission supported funding requests for a school and workshop on X-ray Micro- and Nanoprobes: Instruments, Methodologies and Applications, which was held in Erice, Italy, in June 2007.

(4) The Commission supported a funding request for the 6th International Conference on Inelastic X-ray Scattering (IXS 2007). This is a well established conference, with large international participation and very relevant to the Commission's goals and missions.

(5) The Commission reluctantly gave its support for a funding request by the VIII Latin American Workshop on Magnetism, Magnetic Materials and their Applications (LAW3M 2007), held in Rio de Janeiro, Brazil, 12-16 August 2007. The reluctance was not due to the goals of the workshop, but more to the fact that it was on the border of the Commission's missions.

(6) The Commission supported the funding request for the 9th International Biology and Synchrotron Radiation meeting held in Manchester, UK, in August 2007.

The Commission has been involved in the organization of the Osaka Congress, via its membership of the International Programme Committee (IPC). The Commission has teamed up with the Commissions for Electron Diffraction and Mathematical and Theoretical Crystallography to establish a block of Microsymposia on the use of coherence in X-ray studies. In addition, special sessions on new sources and detectors will be organized.

LINAC-based sources. Another field of attention has been new emerging sources based on linear accelerators (ERLs and FELs). The Commission will continue to pay special attention to raising awareness amongst and to stimulating the use of these LINAC-based sources by crystallographers worldwide. The Commission therefore would like to point out that the term 'synchrotron radiation', both present in the name of the Commission and in its accompanying journal, includes LINAC-based radiation. In this respect, some members of the Commission have been approached by publishing houses that proposed the creation of a new scientific journal: Journal of Free Electron Lasers. The members of the Commission feel that this field is, can be and should be sufficiently covered by the existing IUCr journals.

\section{H. Graafsma, Chair}

\subsection{Commission on XAFS}

The goal for the Commission (CXAFS) continues to be to promote $\mathrm{XAFS}$ in the crystallographic community and to drive new developments.

The web site for the Commission, directly linked from the IUCr web page (http://www.iucr.org/iucr/commissions/cxafs.html), was again developed further and is still hosted by the Physics Department of the University of Bologna, Italy, and maintained by F. Boscherini.

CXAFS supported the 9th International Conference on Biology and Synchrotron Radiation (BSR 2007), Manchester, UK, 13-17 August 2007 (http://www.srs.ac.uk/bsr2007). Furthermore, CXAFS supported the satellite meeting related to this conference: the 3rd BioXAS Study Weekend, SOLEIL, Saint-Aubin, France, 10-11 August 2007, which focused on Metalloproteomics (http://www. synchrotron-soleil.fr/workshops/2007/BIOXAS-SWE).

Many members of CXAFS have put considerable efforts into helping to organize the Osaka Congress. A. Molenbroek is a member of the International Programme Committee. I. Ascone and T. Prangé will organize a Microsymposium (MS63) entitled XAFS in Biocrystallography, and K. Asakura and A. Di Cicco will organize a Microsymposium (MS35) entitled Combined XAFS and Diffraction of Inorganic Structures.

As a joint activity with the Commission on Charge, Spin and Momentum Densities, U. Bergmann and E. Holub-Krappe will organize a Microsymposium (MS94) on Complementary Low-Z Element Absorption Spectroscopy by X-ray Raman Scattering. As a joint activity with the Commission on Electron Diffraction, D. Saldin and F. Boscherini will organize a Microsymposium (MS55) on Surfaces.

As a satellite meeting just before the Osaka Congress, a workshop entitled XAFS Tutorials for Crystallographers and Beginners will be organized by CXAFS and the Institute of Materials Structure Science (Photon Factory), Tsukuba, Japan, 20-23 August 2008.

Finally, the contacts with the International X-ray Absorption Society (IXAS) have been strengthened. This was mainly realized by co-organization of joint events; for example, some of the IXAS members helped organize the Microsymposia and the workshop for the Osaka Congress.

A. Molenbroek, Chair

\section{Sub-committee on the Union Calendar}

The Sub-committee receives and considers requests for IUCr sponsorship and nominal financial support and makes recommendations to the Executive Committee. Acting on the recommendations made by the Sub-committee, during 2007 the Executive Committee approved sponsorship of various schools and meetings, mostly with financial support. Those held in 2007 are listed at the beginning of this Report of the Executive Committee. Those scheduled for 2008, but approved in 2007, are listed below.

II International Workshop on Layered Materials: 'Structure and Properties', Vercelli, Italy, 28-29 March 2008.

Rietveld Refinement Training School, Durham, UK, 30 March - 3 April 2008.

RapiData 2008, Brookhaven, USA, 6-11 April 2008.

International School on Mathematical and Theoretical Crystallography, Gargnano, Italy, 27 April - 3 May 2008.

12th International Workshop on Protein Crystallization, Quintana Roo, Mexico, 6-9 May 2008. 
From Molecules to Medicines: Integrating Crystallography into Drug Discovery, Erice, Italy, 29 May - 8 June 2008.

ACA Annual Meeting, Knoxville, USA, 31 May - 5 June 2008.

European Charge Density Meeting, Gravedona, Italy, 6-11 June 2008.

First K. H. Kuo Summer School of Electron Microscopy and Crystallography: Cryo-Electron Microscopy of Macromolecular Complexes, Beijing, People's Republic of China, 14-16 July 2008.

Organizers of meetings wishing to seek IUCr sponsorship should submit applications at least nine months in advance of the meeting, writing to the Chair of the Sub-committee. The present Chair is Professor G. R. Desiraju. For up-to-date contact information, application procedures and rules, see http://www.iucr.org/iucr/sponsorship/ meetings.html.

Applications for sponsorship of satellite meetings require the approval of the Chair of the Organizing Committee of the main meeting. Meetings (other than satellite meetings) scheduled to be held within two months before or after an IUCr Congress will not be considered for sponsorship. For any meetings scheduled to be held between two and three months before or after a Congress, the application for sponsorship will be sent to the Chair of the Congress Programme Committee for approval, or otherwise. Meetings (other than satellite meetings) scheduled to be held, in the respective region, within 15 days before or after a meeting of a Regional Associate will not be considered for sponsorship. For any meetings scheduled to be held between 15 days and one month before or after a meeting of a Regional Associate, the application for sponsorship requires the approval of the Chair of the Regional Associate Programme Committee.

The IUCr continues to support and uphold ICSU's policy of nondiscrimination and adheres to its decisions and procedures concerning the free circulation of scientists. Organizers of any meetings seeking IUCr sponsorship or support must assure the Calendar Sub-committee that the authorities of the country in which the meeting is to take place guarantee free entrance of bona fide scientists from all countries.

\section{Sub-committee on Electronic Publishing, Dissemination and Storage of Information (CEP)}

B. McMahon attended the Second International Crystal Grid Workshop, Bloomington, USA, 26-28 April 2007 and the Retirement Symposium for S. R. Hall and A. White, University of Western Australia, Perth, Australia, 16-17 July 2007, at both of which he gave presentations describing aspects of the IUCr's publishing and data activities.

B. McMahon was invited to give a presentation on Technology Advances for Promoting Scientific Communication at the WileyBlackwell Executive Seminar, London, 1 June 2007.

\section{Committee for the Maintenance of the Crystallographic Information File Standard (COMCIFS)}

2007 was a year of rapid progress on imgCIF. Thanks in part to workshop funding from DOE, NSF and NIH, issues that had been holding up adoption of imgCIF at beamlines were addressed, new code was written, and we are pleased to report that imgCIF was adopted as the output format for the new Dectris Pilatus 6M detector at the Swiss Light Source in Villigen, Switzerland, and as of early January 2008, ADSC had prepared software to produce imgCIF from all its detectors for use at the Diamond Light Source in Chilton, UK.
Work and workshops will continue in 2008 and the results of this effort will be discussed at the Osaka Congress.

A Microsymposium at the Osaka Congress has been arranged jointly with the Commission on Crystallographic Computing to introduce the DDLm dictionaries and software as well as discuss the interexchange of CIFs with other standards.

The Protein Data Bank continues to extend the content of the wwPDB Exchange Data Dictionary (PDBx). PDBx is a superset of mmCIF, which, in addition to macromolecular X-ray methods, includes structure and experimental representations of NMR, 3D electron microscopy, homology modelling, and experimental details of protein production (http://mmcif.pdb.org). A translated version of this dictionary is maintained as an XML schema (PDBML) (http:// pdbml.pdb.org). In the past year significant extensions have been added to represent large molecular assemblies and more detailed chemical description of both polymer and non-polymer molecular components in macromolecular structures. The wwPDB has released a remediated version of the PDB archive that takes advantage of these latter extensions. This work is described in Remediation of the Protein Data Bank by K. Henrick et al. [Nucleic Acids Res. (2008), 36 (Database Issue), D426-D433; doi:10.1093/nar/gkm937].

Now that CIF is firmly established in the crystallographic community and the nature of the work of COMCIFS is moving from dictionary production to coordinating, it is time to introduce younger members with different expertise into COMCIFS. Half of our membership, including myself, will be retiring at the Osaka Congress and I would like to take this opportunity of thanking H. M. Berman, S. R. Hall and G. Madariaga for the great work they have done in guiding COMCIFS through its first critical years.

\section{D. Brown, Chair}

\section{Committee on Crystallographic Databases}

The Committee has noted the decision of the Executive Committee with respect to new databases (taken in Salt Lake City) that the IUCr will play a neutral, facilitating role with respect to new and existing databases. The Committee also welcomes two new members, A. Hannemann, FIZ, Karlsruhe, Germany (replacement for P. Luksch) and P. Villars, Materials Phases Data System, Vitznau, Switzerland (new member).

\section{G. R. Desiraju, Chair}

\section{IUCr Newsletter}

Five issues of the IUCr Newsletter were distributed in 2007 (Volume 14, No. 4, Volume 15, Nos. 1, 2, 3 and 4). This report will cover the last issue of Volume 14 and all four issues of Volume 15. Volumes 14, No. 4 and 15, No. 4 were 24 pages in length, Volume 15, Nos. 1 and 2 contained 32 pages and Volume 15, No. 3 contained 56 pages, including 36 pages used for the Second Circular for the Osaka Congress. As in previous years, the content covered activities of the IUCr and its Regional Associates and its Commissions, Letters to the Editor, news concerning crystallographers and crystallography in general, awards, elections, resources, obituaries, meeting reports, future meeting announcements, and a general meeting calendar.

Each issue carried a President's column written by Y. Ohashi. Editorial responsibilities for the Newsletter were shared by W. L. Duax and J. Flippen-Anderson.

Each issue devoted two pages to brief summaries of selected articles recently published in IUCr journals. The articles on crystallography in the various countries adhering to the Union continued with Crystallography in Poland, edited by Z. Kosturkiewicz, in 
Volume 15, No. 1, and Crystallography in India edited by G. R. Desiraju in Volume 15, No. 4.

Reports were published covering meetings in Australia, Brazil, Egypt, Israel, Italy, Japan, Pakistan, Portugal, Singapore, Slovenia, South Africa, Spain and the USA.

The mailing list was $2 \%$ smaller than in 2006 with an average distribution of 18 456. Twenty-one countries assist in the effective and economic distribution of the Newsletter. (Distributors: H. Fodil, Algeria; P. Jensen, Australia; J. Valderrama, Colombia; B. KojicProdic, Croatia; J. Hasek, Czech Republic; C. Lecomte and Å. Kvick, France; A. Nangia and Executive Secretary, India; Ismunandar, Indonesia; P. Spadon, Italy; A. Satomi, Japan; A. Hamid Othman, Malaysia; R. Rendle, New Zealand; J. Lipkowski, Poland; M. Costa, Portugal; W. Klooster, Singapore; L. R. Nassimbeni, South Africa; J. Schefer, Switzerland; Yu Wang, Taiwan; K. Haller, Thailand; H. Kooijman, The Netherlands; G. Diaz De Delgado, Venezuela.) Individual distribution was sent to 84 additional countries.

\section{W. L. Duax and J. L. Flippen-Anderson, Editors}

\section{IUCr/Oxford University Press (OUP) Book Series}

In 2007, the cooperation between Oxford University Press (OUP) and the IUCr/OUP Book Series Selection Committee continued to be good.

Two new volumes in the series IUCr Monographs on Crystallography were published: No. 20, Aperiodic Crystals. From Modulated Phases to Quasicrystals, by T. Janssen, G. Chapuis and M. de Boissieu (publication date 24 May 2007); No. 21, Incommensurate Crystallography, by S. van Smaalen (publication date 7 June 2007).

A new volume in the series IUCr Texts on Crystallography was published: No. 9, Theories and Techniques of Crystal Structure Determination, by U. Shmueli (publication date 7 June 2007).

A number of new books are in the production phase and others are in the pipeline. The Committee and the OUP editing staff reviewed a number of proposals and there are contacts with authors about possible new volumes.

The Committee is very interested in proposals for new volumes and encourages prospective authors to contact the Chair of the Committee. (The new Chair of the Committee is Professor D. Viterbo: davide.viterbo@mfn.unipmn.it.) Readers may suggest topics and/or authors as they know the subjects that are not well covered in the literature. Manuscripts covering important aspects of crystallography and related fields are very welcome.

H. Schenk, Chair of Book Series Committee

\section{Regional Associates and Scientific Associates}

\subsection{American Crystallographic Association (ACA)}

As a Regional Associate of the IUCr, the ACA represents not only the crystallographic community in the USA, but also crystallographers from Canada, its associate country. The US National Committee for Crystallography (USNCCr) is the body that represents the USA in the IUCr (on behalf of the US National Academy of Sciences) and works closely with the ACA. It includes a Canadian Representative.

The USNCCr is a self-electing committee and is involved in indicating members for the IUCr Commissions and selecting US delegates to the IUCr General Assembly. It is relevant to mention the activities of the USNCCr in this report since, over the years, very important ACA initiatives dealing with crystallographic education and Inter-American exchange programs have found substantial support from this Committee. In 2007 a USNCCr team prepared a comprehensive report on 'Molecular Structure by Crystallography: Crystallography Education Policies for the Physical and Life Sciences. Sustaining the Science of Molecular Structure in the 21st Century'; this has been completed and is ready to be implemented. This is an important contribution to crystallographic education. It should also be mentioned that, in 2007, the USNCCr organized a Travel Fellowships Program for the IUCr Osaka Congress, to provide partial support for US graduate students, post-doctoral fellows or untenured faculty members in the crystallographic field. The Committee also offered support to Latin-American students to attend the ACA 2007 Small Molecule Crystallography Course (Duquesne University, 9-18 July 2007).

The 2007 Annual Meeting, one of the most important events for the American crystallographic community, was held in Salt Lake City, 22-26 July 2007. Two Workshops were organized during the day prior to the meeting (21 July) and were dedicated to:

(a) SHELX - Refinements of Twins/Disorder and Phasing with $S H E L X C / D / E$;

(b) Standards for Publication of Macromolecular NMR Structures. The highlights of the 2007 Meeting Programme were:

(1) A Plenary Lecture on Thursday 26 July by Nobel Prize Laureate R. D. Kornberg on Structural Basis of Transcription.

(2) The Transactions Symposium on Diffuse Scattering for the Masses - Local Structural Correlation in Molecular, Macromolecular and Inorganic Crystals.

(3) Kenneth N. Trueblood Award Symposium and presentation of award to A. Gavezzotti. Award Lecture: Forty Years of Struggle with Computers over Crystallography and Intermolecular Interactions.

(4) Isidor Fankuchen Award Symposium and presentation of award to F. H. Herbstein. Award Lecture: What can we Learn from the Crystal Structures Reported for Pentacene and for the Anthracene and Tetracyanoquinodimethane (TCNQ) Molecules in their Various Guises?

(5) The Elizabeth Wood Award for science writing was presented to L. Randall.

(6) The M. C. Etter Early Career Award was received by C. Lind. The total number of participants was more than 800 . The morning and afternoon sessions covered the most important topics of crystallography. Poster sessions served as discussion points around the more than 250 presentations. The student travel grants offered by the ACA and the USNCCr once more made possible the participation of 30 young crystallographers from the USA and abroad. Poster prizes awarded were: the Pauling Prize to six of the best poster presentations, including one poster from a Canadian Laboratory, the IUCr best poster award to the best student poster presentation in the area of chemical crystallography or small-molecule structure determination and analysis, the RSCB Protein Data Bank prize for a student poster presentation involving macromolecular crystallography, and the Oxford Cryosystems Award for a poster describing lowtemperature crystallography work.

The next ACA Annual Meeting is scheduled to take place in Knoxville, 31 May - 5 June 2008.

The 2007 ACA Summer School on Macromolecular Crystallography took place at Duquesne University, Pittsburgh, 9-18 July 2007. This is an already traditional eight-day course that provides extensive coverage of single crystal and powder diffraction theory and techniques for a group of around 20-25 students from the USA, Latin America and other countries. The success of this course is well known among students. The lectures covering a wide range of topics 
are very carefully prepared by the dedicated professors, many of whom are members of IUCr Commissions. The students were provided with a CD-ROM containing all notes, presentations and tutorials. The organizers continue doing a wonderful job. Reporting the course activities, C. H. Lake, J. Aitken and B. M. Craven mention the direct financial support of the ACA, the USNCCr and several commercial firms. Participation in this course is a lasting memory for many of the students, who, according to the organizers, provide feedback for future growth and development.

\section{L. Torriani, IUCr Representative}

\subsection{Asian Crystallographic Association (AsCA)}

Activities in early 2007 focused on arrangements for the upcoming AsCA '07 conference to be held in Taipei. In the first half of 2007 the International Programme Committee was busy coordinating and finalizing session topics, Chairs and Co-Chairs for AsCA '07. This was carried out under the highly active chairmanship of Se Won Suh of Korea. Six Plenary Lectures were arranged with a balance of topics and both regional and international representation. The speakers were: Z. L. Wang from Georgia Tech, USA; J. Trewhella, University of Sydney, Australia; K. Lal, National Physical Laboratory, New Delhi, India; O. Nureki, Tokyo Institute of Technology, Japan; K.-H. Lii, National Central University, Taipei; and Y. Shi, Princeton University, USA. Eighteen Minisymposia on various topics were also arranged. Over the summer the deadline for abstract submission to AsCA '07 was extended, which resulted in a final total of 337 submissions. Funding from the IUCr for young scientists was obtained by S.-L. Chang and 41 applications for support were received from around the region with 19 awards being made following careful academic review. The hosting of the AsCA '07 meeting in November by the Taipei delegation was very successful. The consensus was that it continued the trend of increasingly higher standards found for the past several conferences.

Reports on the current status and activities of AsCA were presented at a Council Meeting held during the AsCA '07 conference in Taipei. Full minutes are available at the AsCA web site (http://www.asiancrysassn.org/Council/Minutes/minutes_2007. $\mathrm{htm})$. A variety of important topics were discussed in detail and resolutions passed. After an introductory welcome by outgoing President M. Vijayan, I. D. Williams indicated that the financial status of the society continued to improve and there were JPY 634800 in Japan and AUD 107061 held in Australia, the total thus amounting to ca USD 150 000. S.-L. Chang gave a detailed report on the statistics for the Taipei meeting; a total of 337 abstracts were received, 6 plenary, 96 oral and 235 posters. Of the 412 conference delegates, 295 were international from 20 countries. Importantly, 19 sponsors had supported the hosting of the conference.

Z.-J. Liu then gave a presentation on behalf of Z. Rao for an invited bid to host the AsCA '09 meeting in Beijing, People's Republic of China. This would be run jointly with the Biophysics Society of China, the Chinese Crystallographic Association and the Institute of Biophysics, Chinese Academy of Sciences. The likely venue would be the Beijing International Conference Center (BICC), which is adjacent to the 2008 Olympic site. This could cope with up to 2500 delegates. The dates had not been fixed but would be likely to be in October/November 2009. Se Won Suh next gave details of plans to host AsCA'10 in Korea. Several possible venues were presented and the time again would be likely to be in the autumn. The council members endorsed both bids and also enthusiastically supported A.
Nangia, who followed with a brief presentation on the bid by India to host the IUCr Congress in Hyderabad, India, in 2014.

The election of AsCA office bearers then took place with unanimous consent to J. M. Guss of the University of Sydney, Australia, as new President, Se Won Suh, Seoul National University, Korea, as Vice-President and K. Haller, Suranaree University of Technology, Thailand, as Secretary/Treasurer. Their terms were to commence forthwith and run until the AsCA '10 conference in Korea. Regrettably, S. R. Hall resisted efforts to persuade him to continue in his role as Trustee of the Society. He did, however, put forward two candidates, namely, M. A. Spackman and C. Bond, both from the University of Western Australia, as the new Trustee and as an Associate Trustee, who could provide continuity in the stewardship of the accounts. The council approved their appointment in these respective roles.

Several other important resolutions were reached at the Taipei meeting; the revision of country fees for adhering bodies to AsCA was discussed and passed, and Y. Ohashi's initiative to expand the membership of the IUCr through the possible inclusion of regional members as a group comprising several of the smaller countries of the region was also supported by the AsCA council. After the meeting in Taipei, J. M. Guss, the new AsCA President, was active in following up on this initiative by seeking contact with representatives of several of these nations in order to determine the logistics of this scheme and assist in its implementation.

In summary, AsCA has continued to progress; activities in 2008 will look to formalize the group membership of the IUCr of the smaller regional countries. Further details and finalized venues and dates for the AsCA '09 and AsCA '10 conferences in the People's Republic of China and Korea should be presented at the upcoming Osaka Congress. Assignment of a Chair for the International Programme Committee for AsCA '09 should also take place and be ratified by council members at the Congress. The meeting in Beijing in 2009 is anticipated to strengthen substantially the involvement of crystallographic scientists from China, which should be an important spur to further growth of the society and furtherance of its aims in the next few years.

\section{G. R. Desiraju, IUCr Representative}

\subsection{European Crystallographic Association (ECA)}

The present membership of the ECA Executive Committee is: President: J. R. Helliwell (UK); Vice-President: S. Larsen (France); Secretary: P. Bombicz (Hungary); Treasurer: R. Kuzel (Czech Republic); Members: H. Fuess (Germany), S. Garcia-Granda (Spain), L. van Meervelt (Belgium), A. Roodt (South Africa) and ECA Webmaster M. Nespolo (France, ex officio).

The ECA has acted on the proposal of Y. Ohashi, the IUCr President, that a new category of adherence at the IUCr General Assembly be introduced. The ECA has identified countries that are an ECA member but not yet an IUCr-member country: Latvia, Turkey, Ukraine, Algeria, Morocco and Tunisia. These have been invited and have now agreed to join as an ECA-supported group.

The ECA has supported the following meetings between September 2007 and August 2008:

First Joint Italian Spanish meeting of Crystallography, Calabria, Italy, 24-28 September 2007 (EUR 1000).

International School on Mathematical and Theoretical Crystallography, Gargnano, Italy, 27 April - 3 May 2008 (EUR 1500).

From Molecules to Medicine: Integrating Crystallography in Drug Discovery, Erice, Italy, 29 May - 8 June 2008 (EUR 1500). 
The Zürich Crystallography School 2008, Zürich, Switzerland, 22 June - 5 July 2008 (EUR 500).

Structure Determination from Powder Diffraction Data, Villigen, Switzerland, 18-22 June 2008 (EUR 500).

5th European Charge Density Meeting (ECDM5), Gravedona, Como, Italy, 6-11 June 2008 (EUR 500).

XX International School on Physics and Chemistry of Condensed Matter, Bialowieza, Poland, 5-12 July 2008 (EUR 500).

HEC-X, Bedlewo, Poland, 27-29 September 2007 (EUR 1000).

The ECA is grateful to the IUCr for providing column space on a regular basis in its Newsletter in which the ECA Officers write on topics of policy and community interest within the ECA, and thereby encourage wider debate within the IUCr as a whole. In the upcoming Newsletter the ECA will champion the need for the effort on the education of future generations of crystallographers to be increased at postgraduate, graduate and schools levels. Strong support has been given to a Spanish initiative which it is hoped will serve as preparation for the establishment of a European Undergraduate/Graduate School of Crystallography. The ECA Executive Committee has assigned M. Nespolo to act as its 'Crystallography Education Coordinator'.

Future ECA meetings will be held as follows:

ECM-25 Istanbul, Turkey, August 2009.

ECM-26 Darmstadt, Germany, August 2010 (this will be held along with EPDIC-22).

ECM-27 Bergen, Norway, 2012.

The organization of the programme of ECM meetings has been reviewed, and in future they will more closely follow focus areas as pioneered at ECM-21. The ECA, ECM-25 and ECM-26 will advertise their activities at a booth at the Osaka Congress.

\section{J. Gilmore, IUCr Representative}

\subsection{International Organization for Crystal Growth (IOCG)}

Two meetings, both important for the international crystal growth community, took place in Utah, USA, in August 2007.

The first was the 13th International Summer School on Crystal Growth, Park City (http://www.crystalgrowth.us/isscg13/index.php). The School was attended by 159 postgraduate and postdoctoral students as well as researchers from industry and academia from 24 countries. The School's objective was to provide a series of lectures on theoretical and experimental aspects of growth and characterization of semiconducting, oxide, metallic, organic and biological crystals. Lectures by leading researchers, including E. Vlieg, P. Rudolph and K. Kakimoto, concentrated on crystal growth and epitaxial processes, nanocrystallization, in situ and ex situ characterization, crystal properties, and applications, with a focus on fundamental discussion of the chemical and physical processes that control the assembly of atoms and molecules from the melt, solution or vapour. The level of the School was intended for young researchers interested in fundamental knowledge of crystal growth and epitaxy. The Co-Chairs of ISSCG-13 were J. DeYoreo and C. Wang. D. Bliss worked on the Organizing Committee. The financial support from the IUCr for this School was greatly appreciated. Brief information about the school will be submitted to the IUCr Newsletter.

The other important meeting was the 15th International Conference on Crystal Growth (in conjunction with the 13th Conference on Vapour Growth and Epitaxy and the US Biennial Workshop on Organometallic Vapour Phase Epitaxy) held in Salt Lake City (CoChairs R. Feigelson and G. Stringfellow). D. Bliss, T. Duffar, T. Ohachi and E. Vlieg were among the session's organizers and P. Rudolph presented a Plenary Lecture. The venue was attended by
751 scholars from around the world and more than 640 papers were presented (http://www.crystalgrowth.us/iccg15/index.php). Following the election in early 2007, the new President and Officers of IOCG were confirmed during this meeting. It is my pleasure to announce that R. Fornari and T. Ohachi were elected the Vice-Presidents of the IOCG, whereas H. A. Dabkowska, T. Duffar, K. Kakimoto, P. Rudolph and E. Vlieg were elected to serve as Executive Committee members. The prestigious Frank Prize was awarded to V. Voronkov for 'theoretical contribution to the understanding of defect formation in melt grown crystals, especially in $\mathrm{Si}$, interface structure and shape formation'. The Laudise Prize went to B. Mullin 'for creation of the high-pressure LEC process, the development of MOVPE growth of $\mathrm{HgCdTe}$ alloy and the discovery of non-equilibrium segregation of facets'. V. Bermudez-Benito received the IOCG Schieber (young author) Award, and the rarely bestowed Distinguished Service Award went to I. Sunagawa. These prizes, awarded by IOCG, help to promote crystal growth science in different countries as well as collaboration between national crystal-growth organizations. The next, 16th, ICCG will be organized in Beijing, People's Republic of China, in August 2010, preceded by ISSCG-14 in Dalian, People's Republic of China. J. Wang (a member of the Commission on Crystal Growth and Characterization of Materials) is a Co-Chair of the Local Organizing Committee.

Another (joint) international meeting endorsed by the IOCG in 2007 was the Fifth International Conference on Solid State Crystals and Eighth Polish Conference on Crystal Growth ICSSC-5 and PCCG-8 (http://www.ptwk.org.pl/ICSSC-5-PCCG-8.html).

H. A. Dabkowska, IUCr Representative

\subsection{International Centre for Diffraction Data}

J. A. Kaduk has played a full role as the ICDD representative to the Commission on Powder Diffraction (CPD). The CPD maintains close links with the ICCD and also with IXAS (http://www.i-x-s.org/); IXAS information is available via the ICDD web site at http:// www.icdd.com/ and the IXAS web site at http://www.i-x-s.org/.

W. I. F. David, IUCr Representative

\section{Representatives on Other Bodies}

12.1. IUPAC Interdivisional Committee on Terminology, Nomenclature and Symbols (ICTNS)

ICTNS continued its activities on behalf of IUPAC in reviewing and approving Technical Reports and Recommendations submitted to IUPAC.

The following Technical Reports and Recommendations have been reviewed by referees chosen among IUCr members:

Graphical representation standards for chemical structure diagrams;

Guide to the expression of uncertainty in measurements.

Several of the 'colour' books have undergone revision during the biennium, and these have been reviewed by ICTNS. They include:

Quantities, Units and Symbols in Physical Chemistry (Green Book), 3rd edition, 2007;

Terminology and Nomenclature in Polymer Chemistry (Purple Book), 2nd edition, 2008.

A. Authier, IUCr Representative 


\subsection{International Council for Scientific and Technical Information (ICSTI)}

ICSTI offers a unique forum for interaction among organizations that create, disseminate and use scientific and technical information. ICSTI is a scientific associate of ICSU, the International Council for Science. ICSTI's mission cuts across scientific and technical disciplines as well as international borders, to give member organizations the benefit of a truly global community. An emphasis, started in earnest in its 2007 Public Conference and Workshops, held in June 2007 in Nancy, France, including those planned for 2008, is to understand the possible new practices in knowledge production and knowledge sharing, in particular considering the emerging alternatives to the traditional publishing model that are becoming available for researchers. A growing emphasis is on the need for readers of science results to have a better connection with the primary data. Indeed IUCr journals are widely recognized as a leader in these matters, being awarded a prize for technical innovation from the Association of Learned and Professional Society Publishers (APLSP) in 2007. The planned ICSTI June 2008 Public Conference in Korea includes two Microsymposia on these developments.

The sharing of experimental information via telepresence into the teaching classroom was explored under a NATO-funded Advanced Training Workshop (ATW) (Directors J. R. Helliwell and A. Thalal) held immediately prior to ECM-24, and which proved to be very much appreciated by ATW teachers and students alike in adding new dimensions to such a training event. The telepresence methods used built on trials and experiences within a synchrotron facility beamtime experiment between continents (UK and Morocco). The technical details and methodology have been written up in a Short Communication entitled Science Experiments via Telepresence at a Synchrotron Radiation Facility [Warren, Diakun, Bushnell-Wye, Fisher, Thalal, Helliwell \& Helliwell (2008). J. Synchrotron Rad. 15, 191-194]. This technical development and article also forms a contribution within the Global Information Commons for Science Initiative (GICSI) (http://www.codata.org/wsis/GICSIprospectus.html). GICSI is sponsored by CODATA, ICSTI, INASP, the World Data Centers (WDC) and ICSU, in collaboration with the InterAcademy Panel on International Issues (IAP), the Academies of Science in Developing Countries (TWAS), the OECD, UNESCO, and Science Commons. Specifically the GICSI prospectus includes among its goals 'cooperative sharing of research materials and tools among researchers', which should be supported wherever possible.

Interesting issues have surfaced during 2007 in biological crystallography whereby in one case five publications of several related protein structures were withdrawn owing to a problem with the core diffraction images data analyses being treated on the wrong chirality and in another case a publication appeared to have been based on fabricated diffraction data. This has strengthened the widespread suggestion (for example, see the compelling case presented by Jovine, Morgunova \& Ladenstein (CCP4 bulletin board, 2007) and also the commendation of the proposal by the Editors of Acta Cryst. Sections D and F [Baker, Dauter, Guss \& Einspahr (2008). Acta Cryst. D64, 337-338]\} that diffraction data images should be deposited as core supplementary files accompanying any publication of a biological crystal structure study. An alternative is that journal Notes for Authors make clear that authors confirm their compliance to archive such data for at least ten years (i.e. the same as their research funding agency regulations). There is not yet unanimous community support for the need for centralized data archiving of diffraction images. However, the fast evolution of cheaper computer mass storage is in effect removing one of the major technical obstacles to central archiving. Another practical obstacle is to reach agreement on standardized diffraction image data formats but good progress is being made on this, too, with mmcif image data definitions and work led by H. J. Bernstein and colleagues. There are two very useful and practical outcomes of the debate on this so far. Firstly, the Notes for Authors for IUCr journals for 2008 now include a statement that 'authors are encouraged to make arrangements for the diffraction data images for their structure to be archived'. Secondly, although not necessarily explicitly linked to the diffraction images deposition debate, for PDB depositions from 1 February 2008, structure-factor amplitudes/intensities (for crystal structures) and restraints (for NMR structures) will be a mandatory requirement for PDB deposition (see http://www.pdb.org/pdb/static.do?p=general_information/ news_publications/news/news_2007.html\#20071204). IUCr journals have of course had this policy for a number of years, an important leadership contribution. The advantages of diffraction data images deposition not only extend to making it much more difficult to fabricate data but also allow the building up of a diffuse-scattering archive, thus preserving them for the future when we can fully interpret the scattered intensity between Bragg spots in terms of protein dynamics, clearly a very important field for any consideration of biological function based on structure. The core elements of these developments were tabled by J. R. Helliwell on 5 February 2008 at the ICSTI Winter Committee meeting held in Paris, France.

J. R. Helliwell acknowledges with gratitude the close collaboration with the IUCr Managing Editor, Peter Strickland, and with the IUCr Representative to CODATA, Brian McMahon. A publication on 'Integrating research articles and supporting data' is in press, to be published by these three authors in Learned Publishing Volume 21 Issue 1, the journal of the Society for Scholarly Publishing.

\section{J. R. Helliwell, IUCr Representative}

\subsection{International Council for Science (ICSU)}

The 95th and 96th Meetings of the Executive Board took place in Paris, France, 25-26 April and 11-12 October, respectively.

A meeting of member Unions had been held immediately prior to the April meeting of the Executive Board. This had provided a forum where areas of concern and/or common interest could be explored. The Unions expressed strong support for reinstating a grants programme and commented on the procedure used for appointments to ICSU committees.

The report of the Working Group to Review the Dues' Structure was sent to members for review during the year. The IUCr provided comments that would go back to the Working Group, which will finalize its report for presentation at the General Assembly in 2008.

\subsection{ICSU Committee on Data for Science and Technology (CODATA)}

CODATA hosted or sponsored the following meetings during 2007:

Annual Meeting of the International Association for Social Science Information Service and Technology (IASSIST), Montreal, Canada, 15-18 May 2007. This meeting focused on the theme of Building Global Knowledge Communities with Open Data.

Workshop on Common-Use Licensing of Scientific Data Products, Paris, France, September 2007. This was hosted in collaboration with the Global Biodiversity Information Facility (GBIF) and Science Commons. 
2nd International CODATA Symposium on Generalization of Information, Geneva, Switzerland, 1-3 October 2007.

PV 2007: Ensuring the Long-term Preservation and Value Adding to Scientific and Technical Data, Oberpaffenhofen, Germany, 9-11 October 2007.

International Symposium on LandCover Logic: From Sensors to Cartographic Products and Business Processes, Berlin, Germany, 2930 November 2007.

CODATA also participated actively in the Global Earth Observation (GEO) Summit, Cape Town, South Africa, 27-30 November 2007, at which it presented a White Paper entitled Implementation Guidelines for the GEOSS Data Sharing Principles.

Several CODATA Task Groups also held meetings during the year: The Task Group on Preservation of and Access to Scientific and Technical Data in Developing Countries organized a major workshop in Brazil in May.

The Task Group on Data Sources for Sustainable Development in SADC Countries held its first meeting jointly with the Preservation Task Group in Pretoria, South Africa, 16-17 May.

In March, the Task Group on Fundamental Constants released the 2006 version of the CODATA internationally recommended values of the fundamental physical constants. The new values are available from the NIST web site at http://physics.nist.gov/cuu/Constants/ index.html.

The Task Group on International Polar Year (IPY) Data Policy and Management held its first meeting in conjunction with the launch of the IPY in Paris, France; a second meeting took place in Quebec, Canada, in the autumn.

The Task Group on Anthropometric Data and Engineering met in Banff, Canada in August.

The Task Group on Data Sources in Asian-Oceanic Countries (DSAO) met in Beijing, People's Republic of China, 4-5 December.

Following the ICSU Priority Area Assessment review on Scientific Data and Information, CODATA has moved to develop a Strategic Plan covering the period 2006-2012. A public review draft of the Plan was released in July 2007. The IUCr Representative has provided input to this, as well as to proposed minor modifications to the CODATA constitution.

CODATA appointed P. A. David as a co-opted member of the Executive Committee to take the lead on CODATA-led EU activities promoting the Global Information Commons for Science Initiative (GICSI).

The International Union of Geodesy and Geophysics has joined CODATA.

In 2007 the CODATA Office in Paris moved from the premises it occupied since the late 1970s on boulevard de Montmorency to 5 rue Auguste Vacquerie.

The IUCr CODATA Representative continues to work closely with the ICSTI Representative, J. R. Helliwell, on matters of common interest.

\section{B. McMahon, IUCr Representative}

\subsection{ICSU Committee on Space Research (COSPAR)}

COSPAR's main objective is to promote international collaboration on various levels in scientific research in space, with an emphasis on the exchange of results, information and opinions. Developing world standards for the space environment and its protection requires the creation of national and international organizations and specialist working groups.
In July 2006 the 36th COSPAR Scientific Assembly was held in Beijing, People's Republic of China (http://www.cosparhq.org/). As COSPAR acts mainly as a body responsible for organizing biennial Scientific Assemblies, the year 2007 was devoted to organizing the next meeting, the 37th COSPAR Assembly to be held in Montreal, Canada, 13-20 July 2008 (http://cosparhq.cnes.fr/).

Most COSPAR activities are devoted to space topics (such as astronomy, space travel and exploration or climate research). The most interesting for the IUCr is the COSPAR Scientific Commission on Materials Science in Space (MSS) chaired by R. Narayanan (USA), and Co-Chaired by W.-R. Hu (People's Republic of China), V. Shevtsova (Belgium) and H. Kawamura (Japan); this deals with scientific experiments in materials and fluid sciences performed in space that utilize the physical conditions of space, mainly reduced gravity, for their objectives. Different experiments on growth of crystals in microgravity were often part of these programmes. The MSS Commission reviews fundamental theoretical and experimental approaches, helping to understand emerging fields, and it recommends promising avenues for future research and coordinates exchanges of information on scientific subjects.

The 2007 COSPAR Bureau meeting was held in March in the new location in France.

In 2007 the COSPAR President was R.-M. Bonnet (France) and the Vice-Presidents were W. Hermsen (The Netherlands) and E. C. Stone (USA). Members of the Bureau are: M.-H. Jiang (People's Republic of China), T. Kosugi (Japan), M. E. Machado (Argentina), G. G. Shepherd (Canada), R. Sridharan (India), L. Zelenyi (Russia) and J. B. Zielinski (Poland).

COSPAR co-sponsored the following meetings in 2007:

IHY-Africa Space Weather, Science and Education Workshop, Addis Ababa, Ethiopia, 11-16 November 2007.

Fourth European Space Weather Week, ESA \& Belgian Science Policy Office, Brussels, Belgium, 5-9 November 2007.

Scientific and Fundamental Aspects of the Galileo Programme, ANAE, Bureau des Longitudes, Académie de Marine, and ESA, Toulouse, France, 2-4 October 2007.

URSI/COSPAR International Reference Ionosphere Workshop: Ionosphere-Modelling, Forcing and Telecommunications, Prague, Czech Republic, 10-14 July 2007.

16th Humans in Space Symposium, IAA, Beijing, People's Republic of China, 20-24 May 2007.

The Future of Space Exploration: Solutions to Earthly Problems, Center for Space Physics of Boston University \& Pardee Center for the Study of Longer Range Future, Boston, USA, 12-14 April 2007. International Heliophysical Year (IHY), 2007.

H. A. Dabkowska, IUCr Representative

\section{Finances}

Extracts from the full financial statements, namely the Income and Expenditure account, Balance Sheet and Summary of Fund Accounts, are given in Tables 2, 3 and 4, respectively. ${ }^{1}$ For comparison, the figures for 2006 are provided in italics. The accounts are presented in $\mathrm{CHF}$.

The UNESCO rates of exchange, as issued by the ICSU Secretariat, have been used in the preparation of these accounts. As a consequence of the many fluctuations in exchange rates during the

\footnotetext{
${ }^{1}$ The full audited accounts are available from the IUCr electronic archives (Reference ES0365). Services for accessing these data are described at the back of the journal.
} 
international union of crystallography

Table 2

Income and Expenditure Account (in Swiss Francs) for the year ended 31 December 2007.

\begin{tabular}{|c|c|c|c|c|}
\hline & 2007 & & 2006 & \\
\hline Membership subscriptions & & 152000 & & 153000 \\
\hline Journals, back numbers and single issues & 4881772 & & 4266721 & \\
\hline Books & 396541 & & 112602 & \\
\hline Open Access Grant & 46684 & 5324997 & 85922 & 4465245 \\
\hline Income from investments & 129916 & & 146333 & \\
\hline Bank interest & 34966 & & 18263 & \\
\hline Profit on sale of investments & 106728 & 271610 & 10270 & 174866 \\
\hline \multicolumn{5}{|l|}{ Other income } \\
\hline Royalties and copyright fees & 10206 & & 12139 & \\
\hline Advertising income & 264486 & & 238659 & \\
\hline \multicolumn{5}{|l|}{ Expenditure } \\
\hline \multicolumn{5}{|l|}{ Journals } \\
\hline Publication costs & 993593 & & 960362 & \\
\hline Editorial expenses & 372273 & & 340726 & \\
\hline Technical editing & 1764307 & & 1528058 & \\
\hline Subscription administration & 62992 & 3193165 & 59946 & 2889092 \\
\hline \multicolumn{5}{|l|}{ Books } \\
\hline Publication costs & 58657 & & 29733 & \\
\hline Editorial expenses & 103317 & & 25441 & \\
\hline Technical editing & 205628 & 367602 & 273038 & 328212 \\
\hline \multicolumn{5}{|l|}{ Newsletter } \\
\hline Publication costs & 159019 & & 125424 & \\
\hline General & 658734 & & 636639 & \\
\hline Editors' meetings & 16790 & & 2292 & \\
\hline STAR/CIF & 26100 & & 37350 & \\
\hline Promotion & 196392 & 898016 & 174884 & 851165 \\
\hline Subscriptions paid & & 11609 & & 9709 \\
\hline Visiting Professorship Programme & & 559 & & 1165 \\
\hline \multicolumn{5}{|l|}{ Administration expenses: } \\
\hline General Secretary and Treasurer: Honorarium to Treasurer & 9829 & & 10216 & \\
\hline Audit and accountancy charges & 83333 & & 84971 & \\
\hline Legal and professional fees & 17807 & & 16741 & \\
\hline Travelling expenses & 8012 & & 18584 & \\
\hline Bank charges & 2389 & 121370 & 2307 & 132819 \\
\hline \multicolumn{5}{|l|}{ Executive Secretary's office: } \\
\hline Salaries and expenses & 381062 & & 348306 & \\
\hline Travel expenses of IUCr Representatives on other bodies & 231 & & 8829 & \\
\hline Sponsorship of meetings & 29867 & & 5148 & \\
\hline Congress costs & 74424 & & - & \\
\hline $\mathrm{IUCr} / \mathrm{FIZ}$ agreement & (19 147) & & $(19030)$ & \\
\hline Bad debts & 4000 & 470437 & 7601 & 350854 \\
\hline Depreciation & & 47774 & & 28207 \\
\hline Total expenditure & & 5760493 & & 5068339 \\
\hline
\end{tabular}


Table 2 (continued)

2007

Surplus/(deficit) of income over expenditure

Movement in market value of investments in year

Fluctuation in rates of exchange

Trading activities

Investment activities

Total recognized (losses) and gains relating to the year

Opening fund accounts at 1 January 2007

Closing fund accounts at 31 December 2007
2006

\begin{tabular}{rr}
300797 & \\
\hline$(142019)$ & \\
158778 & $(17223)$ \\
& 29013 \\
& \\
&
\end{tabular}

$(24430)$

406310

381880

$(61365)$

(182 667)

(85 254)

393670

5104584

4710914

5019330

5104584

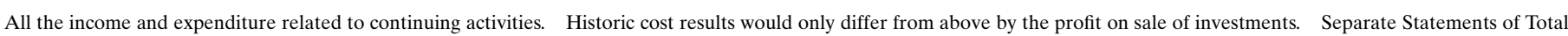
Recognized Gains and Losses and Reconciliation of Movements in the Fund Account are not given, as the information is incorporated in the above.

Table 3

Balance sheet (in Swiss Francs) as at 31 December 2007.

\begin{tabular}{|c|c|c|c|c|}
\hline & 2007 & & 2006 & \\
\hline \multicolumn{5}{|l|}{ Fixed assets } \\
\hline Tangible fixed assets & & 45456 & & 52119 \\
\hline \multirow[t]{2}{*}{ Investments at market value } & & 3663796 & & 4236550 \\
\hline & & $\overline{3709252}$ & & 4288669 \\
\hline \multicolumn{5}{|l|}{ Current assets } \\
\hline Stock & & 200701 & & 270364 \\
\hline \multicolumn{5}{|l|}{ Cash at bank and in hand } \\
\hline Current accounts & 28811 & & 15437 & \\
\hline Deposit and savings accounts & 637242 & & 1503441 & \\
\hline Cash with Union officials & 17161 & 683214 & 17575 & 1536453 \\
\hline Debtors, accrued income and payments in advance & & 878821 & & 684040 \\
\hline Subscriptions due from Adhering Bodies & & 39000 & & 57000 \\
\hline Total current assets & & 1801736 & & 2547857 \\
\hline Creditors: amounts falling due within one year & & (491 658) & & (1 731942$)$ \\
\hline Net current assets & & 1310078 & & 815915 \\
\hline Total funds & & 5019330 & & 5104584 \\
\hline
\end{tabular}

year, the following procedure has been adopted for the accounts. Assets and liabilities in currencies other than CHF at 31 December 2007 have been translated into CHF in the balance sheet at the rate operative at that date. For the income and expenditure accounts, transactions have been translated into CHF by applying the rates appropriate to the individual dates of these transactions. As a consequence of the fluctuation in exchange rates, overall an apparent loss has arisen on the assets of the Union, in terms of CHF, amounting to CHF 244 032. The loss attributable to investment activities has been assigned to the General Fund and the loss attributable to trading activities has been divided amongst the fund accounts in direct proportion to the balances on these accounts at 31 December 2007. It should be noted that this overall loss in CHF is not a real loss of money, but rather a loss on paper resulting from the accounts being expressed in CHF.

Investments are noted in the balance sheet at their market value at 31 December 2007.
The balance sheet shows that the assets of the Union, including the loss of CHF 244032 resulting from fluctuations in rates of exchange, have decreased during the year, from CHF 5104584 to CHF 5019 330. The movement in market value of the investments was CHF -142019 in 2007 (CHF 406310 in 2006).

A transfer of CHF 120000 was made to the Publications and Journals Development Fund from the Acta Crystallographica Fund. A transfer of CHF 160000 was made to the Research and Education Fund from the Acta Crystallographica Fund. A transfer of CHF 150000 was made to the General Assembly and Congress Fund from the Acta Crystallographica Fund. A transfer of CHF 50000 was made to the Newsletter Fund from the Journal of Applied Crystallography Fund. A transfer of CHF 5000 was made to the President's Fund from the Journal of Applied Crystallography Fund. A transfer of CHF 50000 was made to the General Assembly and Congress Fund from the Journal of Applied Crystallography Fund.

The following comments refer to figures in the full accounts. 
international union of crystallography

Table 4

Summary of Fund Accounts (in Swiss Francs) as at 31 December 2007

\begin{tabular}{|c|c|c|c|c|c|c|c|}
\hline & \multirow{2}{*}{$\begin{array}{l}\text { As at } \\
\text { 1 January } 2007\end{array}$} & \multirow[t]{2}{*}{$\begin{array}{l}\text { Transfers } \\
\text { between } \\
\text { funds }\end{array}$} & \multirow[t]{2}{*}{$\begin{array}{l}\text { (Deficit)/ } \\
\text { surplus of } \\
\text { income over } \\
\text { expenditure } \\
\text { for the } \\
\text { year }\end{array}$} & \multirow[t]{2}{*}{$\begin{array}{l}\text { Increase in } \\
\text { market } \\
\text { value of } \\
\text { investments }\end{array}$} & Fluctuations & xchange rates & \multirow[t]{2}{*}{$\begin{array}{l}\text { Balance } \\
\text { at } 31 \text { December } \\
2007\end{array}$} \\
\hline & & & & & Trading & Investments & \\
\hline \multicolumn{8}{|l|}{ Fund accounts } \\
\hline General Fund & 767606 & - & (190 250) & (142 019) & (5 075) & (182 667) & 247595 \\
\hline International Tables & (164 027) & - & $(39829)$ & - & 2377 & - & (201479) \\
\hline Publications and Journals Development Fund & 826563 & 120000 & $(34834)$ & - & $(10630)$ & - & 901099 \\
\hline Research and Education Fund & 991693 & 160000 & (155 828) & - & (11 611) & - & 984254 \\
\hline Ewald Fund & 523147 & - & 13079 & - & $(6252)$ & - & 529974 \\
\hline Newsletter Fund & 102698 & 50000 & (77 810) & - & (873) & - & 74015 \\
\hline Journal of Synchrotron Radiation & 70738 & - & (7 595) & - & (736) & - & 62407 \\
\hline General Assembly and Congress & - & 200000 & (165 125) & - & (407) & - & 34468 \\
\hline
\end{tabular}

The General Fund account shows a deficit of CHF 190250 , as compared with a deficit in 2006 of CHF 229 913. The administrative expenses were CHF 506617 in 2007 as compared with CHF 486057 in 2006. Of this amount, CHF 239967 was charged to the publications of the Union.

The expenses of the Union Representatives on other bodies were CHF 231. The cost of the Finance Committee meetings held in 2007 was CHF 19490 , while the Executive Committee meeting cost CHF 65 772. The income from the IUCr/Fachinformationszentrum agreement (to provide low-cost copies of the Inorganic Crystal Structure Database) was CHF 19 148. The subscriptions from Adhering Bodies were CHF 152 000. Interest on bank accounts and investments credited to the General Fund was CHF 109968.

The President's Fund, the Publication and Journals Development Fund, the Research and Education Fund and the Ewald Fund received interest, at a nominal rate of $2.5 \%$ per annum, on the balances in the funds.

The President's Fund therefore received interest of CHF 2138. Grants totalling CHF 9181 were paid from the fund in 2007.

The Acta Crystallographica account for 2007 shows a surplus of CHF 704811 before the transfer of CHF 430000 to the other fund accounts, as compared with a surplus of CHF 555402 in 2006 before the transfer of CHF 360000 to the other fund accounts.

The subscription rates were increased for 2007. In 2007, the number of paid subscriptions to Acta Crystallographica were as follows: Section A 624 (664) including 47 (57) personal subscriptions (values for 2006 are given in parentheses); Section B 602 (631) including 36 (48) personal subscriptions; Section C 581 (600) including 30 (34) personal subscriptions; Section D 607 (647) including 86 (97) personal subscriptions. The cost of the technicalediting office has been divided between the Acta Crystallographica, the Journal of Applied Crystallography, the Journal of Synchrotron Radiation and the International Tables accounts in percentages based on the staff time spent on each publication. The technical-editing costs (comprising salaries and expenses, computer expenses and depreciation of office equipment) for Acta Crystallographica were CHF 1609277 [for 13708 published pages (5376 papers)] as compared with CHF 1336642 in 2006 [15 830 published pages (6637 papers)]. The journal's accounts have also been charged with administration expenses as in previous years as shown in the General Fund.

The Journal of Applied Crystallography account shows a surplus of CHF 261 220, as compared with a surplus of CHF 271903 in 2006. In
2007, the number of paid subscriptions, including 64 (77 in 2006) personal subscriptions, was 555 (588 in 2006).

The Journal of Synchrotron Radiation account shows a deficit of CHF 7595, as compared with a surplus of CHF 3378 in 2006. In 2007, the number of paid subscriptions, including 47 (48 in 2006) personal subscriptions, was 200 (202 in 2006).

The International Tables account shows a deficit of CHF 39 829, as compared with a deficit of CHF 300781 in 2006. The net sales income was CHF 293430 in 2007 as compared with CHF 85539 in 2006. The significant difference is largely attributable to the fact that the income for 2006 includes an adjustment for sales for Volume G in 2005 (an internal transfer of 500 copies was wrongly attributed to sales in 2005).

The Newsletter Fund account received a transfer of CHF 50000 from the Journal of Applied Crystallography Fund in 2007 (and in 2006). The cost to the Union of producing the Newsletter in 2007 was CHF 77810 (CHF 82404 in 2006).

As mentioned earlier, the income for the President's Fund account, the Publications and Journals Development Fund account, the Research and Education Fund account and the Ewald Fund account includes interest as well as transfers from other fund accounts. In the Publications and Journals Development Fund account, the computing and promotion expenses are divided between the General Fund, the Acta Crystallographica Fund, the Journal of Applied Crystallography Fund, the Journal of Synchrotron Radiation Fund and the International Tables Fund. STAR/CIF costs, Special Issue costs, journal grants and web input costs are also charged to the Publication and Journals Development account. From 2000, costs associated with the Crystallographic NeXus Project to provide CDROMs (containing crystallographic software and web material) free of charge to developing countries has been charged to this Fund. In 2007, CHF 45353 was provided from this Fund as journal subsidies in connection with the Journal Grants Fund, which was set up to assist institutions that have difficulties in meeting the full subscription price. CHF 175656 for financial support to young scientists, to enable them to attend scientific meetings sponsored by the Union, was charged to the Research and Education Fund.

A General Assembly and Congress Fund has been established so that the costs associated with the General Assembly and Congress can be spread over the triennium. In 2007 this Fund incurred expenses totalling CHF 165125 and received transfers of CHF 150000 from the Acta Crystallographica Fund and CHF 50000 from the Journal of Applied Crystallography Fund. 